\title{
Dissolved Fe across the Weddell Sea and Drake Passage: impact of DFe on nutrient uptake
}

\author{
M. B. Klunder ${ }^{1, *}$, P. Laan ${ }^{1}$, H. J. W. De Baar ${ }^{1,2}$, R. Middag ${ }^{1,3}$, I. Neven ${ }^{4}$, and J. Van Ooijen ${ }^{5}$ \\ ${ }^{1}$ Department of Biological Oceanography, Royal Dutch Institute for Sea Research, Landsdiep 4,1797 SZ Texel, \\ the Netherlands \\ ${ }^{2}$ Department of Ocean Ecosystems, University of Groningen, Kerklaan 30,9751 NN Haren, the Netherlands \\ ${ }^{3}$ University of Otago, Department of Chemistry, NIWA/UO Research Centre for Oceanography, P.O. Box 56, Dunedin 9054, \\ New Zealand \\ ${ }^{4}$ Department of Plant Physiology, University of Groningen, Kerklaan 30, 9751 NN Haren, the Netherlands \\ ${ }^{5}$ Department of Chemical Oceanography, Royal Dutch Institute for Sea Research, Landsdiep 4,1797 SZ Texel, \\ the Netherlands \\ *now at: Dutch board for the authorisation of biocides and plant protection produces, Wageningen, the Netherlands
}

Correspondence to: M. B. Klunder (maartenklunder@hotmail.com)

Received: 10 March 2013 - Published in Biogeosciences Discuss.: 29 April 2013

Revised: 4 December 2013 - Accepted: 9 December 2013 - Published: 6 February 2014

\begin{abstract}
This manuscript reports the first full depth distributions of dissolved iron (DFe) over a high-resolution Weddell Sea and Drake Passage transect. Very low dissolved DFe concentrations (0.01-0.1 nM range) were observed in the surface waters of the Weddell Sea, and within the Drake Passage polar regime. Locally, enrichment in surface DFe was observed, likely due to recent ice melt (Weddell Sea) or dust deposition (Drake Passage). As expected, in low DFe regions, usually a small silicate drawdown compared to the nitrate drawdown was observed. However, the difference in drawdown between these nutrients appeared not related to DFe availability in the western Weddell Sea. In this region with relatively small diatoms, no relationship between $\mathrm{N}: \mathrm{P}$ and $\mathrm{N}$ : Si removal ratios and DFe was observed. In comparison, along the Greenwich Meridian (Klunder et al., 2011a), where diatoms are significantly larger, the $\mathrm{N}: \mathrm{P}$ and $\mathrm{N}: \mathrm{Si}$ removal ratios did increase with increasing $\mathrm{DFe}$. These findings confirm the important role of DFe in biologically mediated nutrient cycles in the Southern Ocean and imply DFe availability might play a role in shaping phytoplankton communities and constraining cell sizes.

Over the shelf around the Antarctic Peninsula, higher DFe concentrations $(>1.5 \mathrm{nM})$ were observed. These elevated concentrations of Fe were transported into Drake Passage along isopycnal surfaces. Near the South American conti-
\end{abstract}

nent, high ( $>2 \mathrm{nM}$ ) DFe concentrations were caused by flu$\mathrm{vial} /$ glacial input of DFe.

On the Weddell Sea side of the Peninsula region, formation of deep water (by downslope convection) caused relatively high $\mathrm{Fe}(0.6-0.8 \mathrm{nM})$ concentrations in the bottom waters relative to the water masses at mid-depth $(0.2-0.4 \mathrm{nM})$. During transit of Weddell Sea Bottom Water to the Drake Passage, through the Scotia Sea, additional DFe is taken up from seafloor sources, resulting in highest bottom water concentrations in the southernmost part of the Drake Passage in excess of $1 \mathrm{nM}$. The Weddell Sea Deep Water concentrations $(\sim 0.32 \mathrm{nM})$ were consistent with the lowest DFe concentrations observed in Antarctic bottom water in the Atlantic Ocean.

\section{Introduction}

It is now well established that phytoplankton growth in the high nutrients low chlorophyll (HNLC) Southern Ocean is primarily limited by low Fe concentrations (De Baar et al., 1990; Buma et al., 1991; De Baar et al., 1995, 1999; Measures and Vink, 2001; Boyd et al., 2007; Sedwick et al., 2008; Pollard et al., 2009; Smetacek et al., 2012), likely in combination with light limitation (Mitchell et al., 1991; Lancelot 
Table 1. Size and volume of diatom species at the zero meridian and eastern Weddell Sea stations.

\begin{tabular}{|c|c|c|c|c|}
\hline & \multirow[t]{2}{*}{ Stations } & \multirow[t]{2}{*}{ Biovolume/cell } & \multicolumn{2}{|c|}{ Percentage of species } \\
\hline & & & $\begin{array}{c}\text { Large } \\
\left(>5000 \mu \mathrm{m}^{3}\right) \\
(\%)\end{array}$ & $\begin{array}{c}\text { Small } \\
\left(<1000 \mu \mathrm{m}^{3}\right) \\
(\%)\end{array}$ \\
\hline Greenwich & 150 & 3408 & 78 & 5 \\
\hline \multirow[t]{5}{*}{ Meridian } & 167 & 8436 & 87 & 2 \\
\hline & 161 & 8272 & 88 & 2 \\
\hline & 178 & 7810 & 82 & 2 \\
\hline & Average & 6981 & 84 & 3 \\
\hline & Standard deviation & 2397 & 5 & 1 \\
\hline Eastern & 191 & 7420 & 94 & 5 \\
\hline \multirow[t]{6}{*}{ Weddell Sea } & 193 & 4506 & 74 & 5 \\
\hline & 198 & 2735 & 49 & 7 \\
\hline & 204 & 3390 & 75 & 7 \\
\hline & 210 & 3240 & 57 & 12 \\
\hline & Average & 4258 & 70 & 7 \\
\hline & Standard deviation & 1882 & 18 & 3 \\
\hline Difference* & & 0.048 & 0.084 & 0.018 \\
\hline
\end{tabular}

* One sided homeoscedastic $t$ test.

et al., 2000; De Baar et al., 2005) as well as photo-inhibition (Alderkamp et al., 2010, 2011).

North of the Antarctic Peninsula, the eastward flowing Antarctic circumpolar current (ACC) is forced through the narrow $(800 \mathrm{~km})$ Drake Passage, resulting in strong velocities (Sokolov and Rintoul, 2007). The distribution of dissolved $\mathrm{Fe}(\mathrm{DFe})$ in the region around the Antarctic Peninsula has been relatively well studied in recent years (SanudoWilhelmy et al., 2002; Lin et al., 2011, Dulaiova et al., 2009; Ardelan et al., 2010). Additionally, several studies have reported dissolved $\mathrm{Fe}(\mathrm{DFe})$ values in the upper waters of the Weddell Sea (Sanudo-Wilhelmy et al., 2002; Lannuzel et al., 2008; Lin, 2011, Croot, 2004), but there have been few full water column studies on dissolved $\mathrm{Fe}$ in this area (De Jong et al., 2012) and no full water column DFe data was available for the Drake Passage. The GEOTRACES program of the International Polar Year 2007-2008 was designed to produce the first-ever deep ocean sections of dissolved Fe (DFe) and other (bio-essential) trace metals in the polar oceans. The expedition ANT/XXIV/3 aboard ice-breaker R/V Polarstern in 2008 (Fahrbach et al., 2011) thus comprises the two first deep sections of dissolved Fe across the Weddell Sea and Drake Passage, respectively. These are reported here and compared with previously published data from a complete deep section of dissolved $\mathrm{Fe}$ along the Greenwich Meridian (Klunder et al., 2011a).

There are several input sources of Fe to the surface waters of the Southern Ocean. Possibly the most important is the supply of Fe-rich deep waters from below (De Baar et al., 1995 (their Table 1); Löscher et al., 1997; Hoppema et al., 2003; Croot et al., 2004; Klunder et al., 2011a). Atmospheric dust deposition is deemed to be very low in this region (Jickells et al., 2005), but melting of free floating icebergs that carry sediments has been shown to supply Fe locally (Löscher et al., 1997; Lin et al., 2011). Both atmospheric dust input and iceberg melting are episodic, and a challenge to assess in basin wide or annual supply estimates. Nevertheless, the modelling results from Raiswell (2011) indicated that input of bio available Fe to the Weddell Sea by icebergs may be as large as total dust input. Rare events of dust deposition were observed along the Greenwich Meridian (Middag et al., 2011a, b). Klunder et al. (2011a) found these sources of DFe to be smaller, around instead of one sixth to one fifth of the upwelling and vertical mixing, in this part of the Southern Ocean. Anoxia in pore waters of shelf sediments causes dissolution of reduced $\mathrm{Fe}$ (Elrod et al., 2004) that enters the overlying water by sediment resuspension (Luther and $\mathrm{Wu}, 1997$ ) and/or eddy diffusion. These Fe enriched shelf waters were found around and beyond the Antarctic Peninsula (Dulaiova et al., 2009) and near island archipelagos like the Kerguelen Plateau (Bucciarelli et al., 2001; Blain et al., 2007; Chever et al., 2010a) and Crozet islands (Planquette et al., 2007) due to entrainment and mixing. In the Drake Passage, eddy activity may involve both upwelling and downwelling and thereby influence the distribution of DFe (Kahru et al., 2007).

It has been suggested that limited availability of $\mathrm{DFe}$ for phytoplankton may influence the uptake ratio of nutrients in the Southern Ocean (De Baar et al., 1997; Takeda, 1998; Marchetti and Cassar, 2009). Upon Fe deficiency 


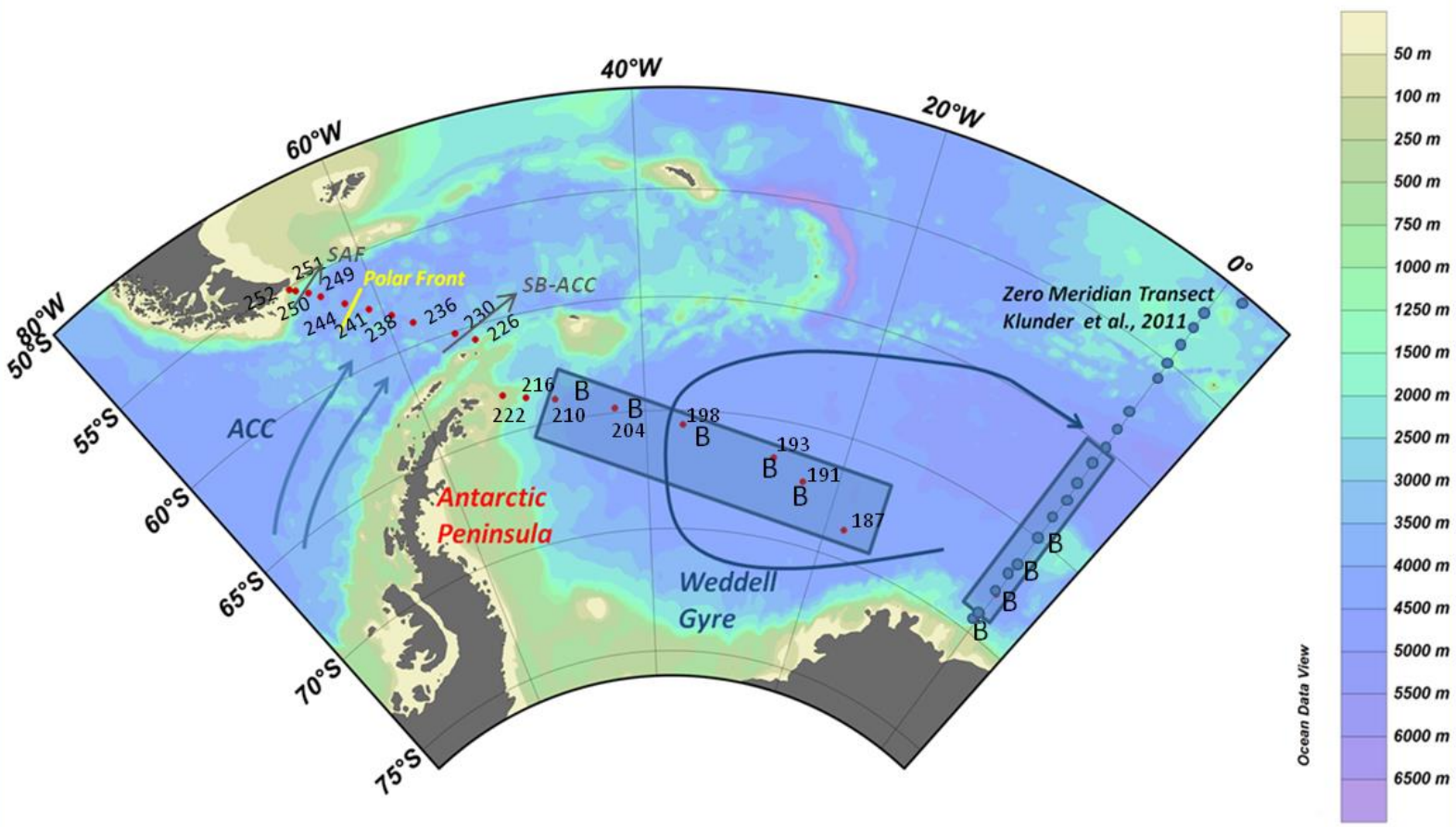

Fig. 1a. Sampling region including Weddell Sea and Drake Passage stations (red dots). Also shown are the general flow directions (blue arrows) of the Weddell Gyre and Antarctic circumpolar current (ACC) and the subantarctic front (SAF) at 55.6 $6^{\circ}$ in the northern and the southern boundary of the ACC (SB-ACC) at $60.4^{\circ} \mathrm{S}$ in the south (both greyscale). Within the ACC, the polar front (PF) is found at $57.3^{\circ} \mathrm{S}$ (yellow)). The westward geographic boundary of the Weddell Sea is the Antarctic Peninsula up to Elephant Island, the traditional eastward boundary at Cap Norvegia $\left(12^{\circ} \mathrm{W}\right)$. Please be aware that the Weddell Gyre extends far more eastwards to $\sim 20^{\circ}$ E. The blue shaded boxes show the stations for which nutrient removal is calculated (see main text; Figs. 6 and 8). Stations for which biological (phytoplankton) data is available are marked with a "B" (see text). The stations from the transect over the zero meridian (Klunder et al., 2011a) are marked as blue dots.

the cellular $\mathrm{N}$ content decreases due to impairment of $\mathrm{Fe}$ requiring enzymes nitrate reductase and nitrite reductase required for ultimate production of amino acids (i.e. the protein content of cells decreases). This implies a lower N:P element ratio of plankton. For diatoms, which generally continue to produce the opaline $\left(\mathrm{SiO}_{2}\right)$ frustules, this implies a lowering of their overall N : Si content (Takeda et al., 1998 and overview by Marchetti and Cassar, 2009). Moreover, Hoppema et al. (2007) have shown less Si removal relative to $\mathrm{C}$ removal and less Si removal relative to $\mathrm{N}$ removal in the surface waters approaching the Peninsula region, which they attributed to increasing DFe availability.

In the deep Southern Ocean waters, the North Atlantic Deep Water (NADW) enters the ACC at $\sim 2000-3000 \mathrm{~m}$ depth (Klunder et al., 2011a). This iron-rich water mass ( $\mathrm{Fe}=\sim 0.7 \mathrm{nM})$ eventually flows into the Weddell Sea as warm deep water (WDW). The return flow to the ACC consists of Weddell Sea Bottom Water (WSBW) and Weddell Sea Deep Water (WSDW) (see Sect. 3). The deep Drake Passage is dominated by circumpolar deep waters which contain generally $\sim 0.4-0.5 \mathrm{nM}$ DFe (Klunder et al., 2011a). However, at $\sim 2000 \mathrm{~m}$ depth at the Patagonian continental shelf, an additional water mass derived from the East Pacific
Ocean, carrying properties of hydrothermal origin (Well et al., 2003; Sudre et al., 2011) was observed, which forms a potential source of DFe to the deep Drake Passage.

In this study we present the distribution of dissolved $(<0.2 \mu \mathrm{m}$ fraction) DFe over two combined transects, one crossing the Weddell Sea and one crossing the Drake Passage. The first transect comprised 8 stations in the Weddell Sea, from the central Weddell Sea $\left(17^{\circ} \mathrm{E}\right)$ towards the Antarctic Peninsula shelf close to Joinville Island (Fig. 1a). The other transect stretched from Elephant Island (Fig. 1b) on the northeast shelf of the Antarctic Peninsula, across Drake Passage to the continental shelf of South America.

The simultaneous sampling for trace metals (Middag et al., 2011a, b, 2012), major nutrients $\left(\mathrm{Si}, \mathrm{NO}_{3}, \mathrm{PO}_{4}\right)$, biological parameters (Rutgers van der Loeff et al., 2011; Neven et al., 2011) and physical parameters (Fahrbach et al., 2011) allowed us to investigate the input sources of DFe from the Antarctic Peninsula to the surrounding Weddell Sea and Drake Passage waters, and to estimate the relative nutrient removals in relation to DFe concentrations. Additionally, other sources and sinks of DFe in the Weddell Sea and Drake Passage are discussed. The DFe data presented here were collected in March 2008, thus towards the end of the growing 


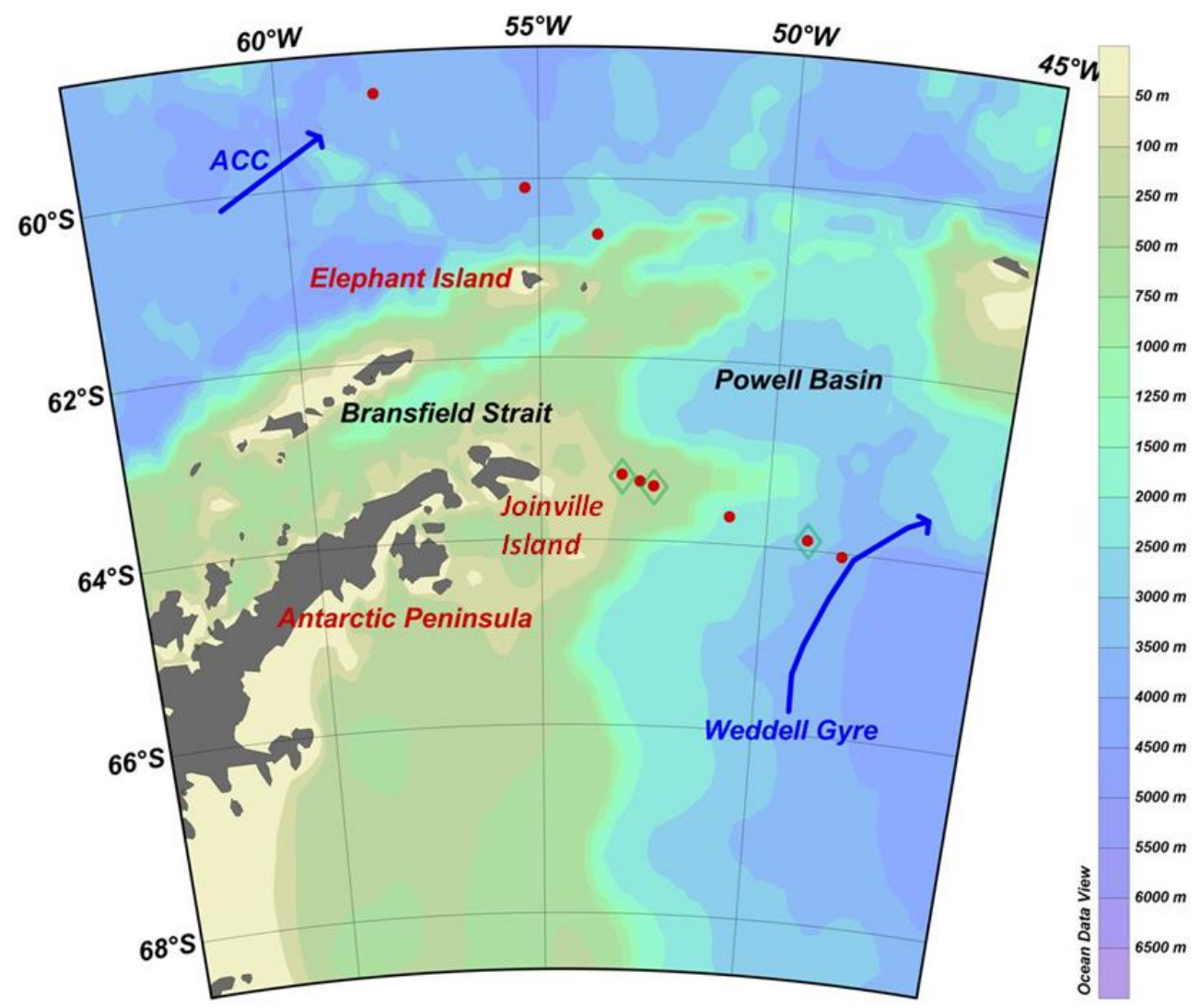

Fig. 1b. Overview of Peninsula region at expanded regional scale. Sample stations are indicated with red dots; green diamonds mark stations with less than five samples, whereas regular stations have 24 samples. Flow directions of Weddell Gyre and ACC are indicated schematically with blue arrows.

season, when DFe may have been depleted and limiting for phytoplankton growth (Sedwick et al., 2000). This would have been reflected in nutrient removal in the months prior to our sampling. Using the deficit between the remnant winter water and the surface waters an estimation of this nutrient removal could be made (Hoppema et al., 2007). Here we present estimates for such removal and investigated their relation with DFe availability.

\section{Methods}

\subsection{Sampling and analysis}

Water samples were collected during the ANT XXIV/3 expedition of $\mathrm{R} / \mathrm{V}$ Polarstern between 15 March and 12 April 2008 (Fig. 1a). Samples were taken and analysed under trace metal clean conditions extensively described by De Baar et al. (2008) and Klunder et al. (2011a). Seawater was filtered over a $0.2 \mu \mathrm{m}$ filter cartridge (Sartrobran-300, Sartorius) under nitrogen pressure. For each depth, replicate samples of DFe were taken in $60 \mathrm{~mL}$ LDPE sample bottles and acidified to $0.024 \mathrm{M} \mathrm{HCl}$ (Baseline $\mathrm{HCl}$, Seastar Chemicals) and left overnight, resulting in a $\mathrm{pH}$ of $\sim 1.8$. All bot- tles, used for storage of reagents and samples, were acid cleaned according to a three step cleaning procedure, as described by Middag et al. (2009). We ensured all the Fe was in the Fe (III) form, by adding $60 \mu \mathrm{L}$ of $1 \%$ o hydrogen peroxide (Merck Suprapur 30\%), at least one hour before measurement. The DFe was measured using flow injection analysis with luminol chemiluminescence, where DFe was preconcentrated on an IDA Toyopearl AF-Chelate resin (Klunder et al., 2011a). After pre-concentration, the column was rinsed $(60 \mathrm{~s})$ with de-ionized ultrapure (DI) water $(18.2 \mathrm{M} \Omega$ ) and subsequently $\mathrm{Fe}$ was eluted from the column (120 s) using $0.4 \mathrm{M} \mathrm{HCl}$ (Merck Suprapur). Pre-concentration time was usually 120 seconds.

\subsection{Calibration and validation}

The system was calibrated using standard additions of $\mathrm{Fe}$ to low DFe seawater collected in the region. For all samples a duplicate sample was taken. For outlying values, profiles of the other trace metals dissolved aluminium (DAl) and manganese (DMn) as well as nutrients and physical parameters (e.g. light-transmission) were evaluated for consistency. In case no deviations were observed in the other physical, 
chemical and biological parameters and both the initial and duplicate sample showed an exceptional value, the exceptional data point was considered as erroneous if the value deviated more than $25 \%$ from the expected profile based on linear interpolation between the DFe concentration in the seawater samples above and below the data point (after Middag et al. 2011a, b and Klunder et al., 2011a). Any truly elevated DFe concentration would be reflected in the corresponding chemical or physical parameters; therefore, this is considered an acceptable approach regarding outlying values. Each sample was analysed three times (three peaks) and standard deviation was generally below $5 \%$.

Regularly the combined blank of the 1 min MQ-column wash and the $0.4 \mathrm{M} \mathrm{HCl}$ for elution of the column was calculated from the amount of counts measured upon zero (0) seconds loading time. The average value for this blank was $14 \pm 11 \mathrm{pmol}(n=18)$ and this blank did not exceed $40 \mathrm{pM}$. By double versus single addition of the $\mathrm{H}_{2} \mathrm{O}_{2}$ it was found that this did not cause a quantifiable blank. The contribution of the Seastar Baseline Hydrochloric Acid is deemed to be negligible $(0.04 \mathrm{pM} / \mathrm{sample}$; see Klunder et al., 2011a). The detection limit was determined regularly and defined as the standard deviation of 5 peaks of $10 \mathrm{~s}$ loading of low-Fe seawater (subsurface minimum), multiplied by 3 . The average detection limit was typically $9 \pm 5 \mathrm{pM} \mathrm{Fe}(n=7)$, and the detection limit did not exceed $17 \mathrm{pM} \mathrm{Fe}$. Therefore, in this study, all values $<0.01 \mathrm{nM}$ are presented as $0.01 \mathrm{nM}$.

In order to validate the accuracy of the system, standard reference seawater (SAFe surface (S) and SAFe deep (D2)) was measured regularly, in triplicate. The average concentrations we found were $0.085 \pm 0.023 \mathrm{nM}(n=16)$ and $0.958 \pm 0.039(n=13)$ for SAFe S and SAFE D2 respectively. These results were consistent with the community consensus values $0.095 \pm 0.008 \mathrm{nM}\left(0.093 \mathrm{nmol} \mathrm{kg}^{-1}\right)$ for $\mathrm{SAFe} S$ and $0.956 \pm 0.026 \mathrm{nM}\left(0.933 \mathrm{nmol} \mathrm{kg}^{-1}\right)$ for SAFe D2 (www.geotraces.org; data sheet version May 2013).

\subsection{Calculation of net nutrient removal}

In order to investigate the relationship between DFe and net nutrient removal in the Weddell Sea the seasonal nutrient uptake in the upper layer above the winter water was calculated. The method and the assumptions needed are described in more detail by Hoppema et al. (2002, 2007). Briefly, the difference in nutrient concentration between the winter water (subsurface potential temperature $(\theta)$ minimum $<-1.6^{\circ} \mathrm{C}$ ) and the overlying surface water was calculated. Next, upon vertical integration over the upper layer depth interval, the net seasonal nutrient removal from the upper layer, relative to the winter water was obtained. In order to correct for spatial variations in diluting melt water, concentrations were normalized to a salinity of 34.5 . For comparison, also the net removal for the stations situated within the Weddell Gyre at the Greenwich Meridian at $0^{\circ} \mathrm{W}$ (Klunder et al., 2011a) were included. The stations with a distinct winter water layer, allow-

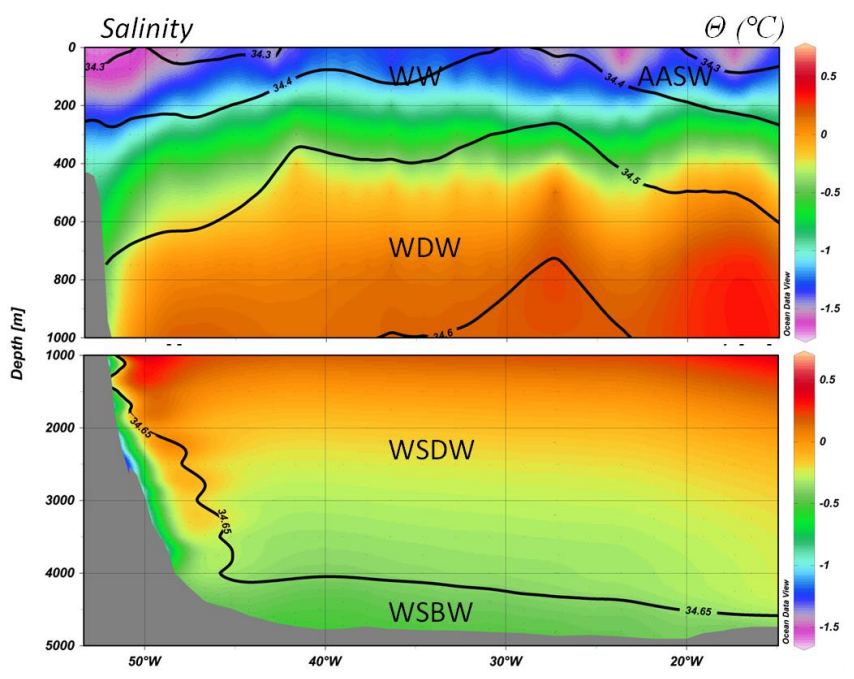

Fig. 2a. Potential temperature (color) and salinity (black contour lines) full depth section of the Weddell Sea transect. Approximate location of water masses is indicated.

ing nutrient removal calculation, were situated between 60 $69^{\circ} \mathrm{S}$ at the Greenwich Meridian and between $17-48.5^{\circ} \mathrm{W}$ in the west Weddell Sea transect and are marked by the two shaded area's in Fig. 1a. Moreover, the phytoplankton community was a relevant factor in the relation between DFe and nutrients; therefore, also the available data about the phytoplankton community was included in the discussion. Stations for which phytoplankton data is available are marked with a "B" in Fig. 1a. More details on the phytoplankton data can be found in electronic Supplement S1 and S2 and in Neven et al. (2011).

\section{Hydrography}

Transport of water masses in the Weddell Sea is dominated by the Weddell Gyre, a cyclonic current, with its westward component near the Antarctic continent and an eastward component along Bouvet ridge (Fig. 1a; Klatt et al., 2005; Fahrbach, 2004). Although the Weddell Sea as a whole is influenced by the gyre, the strongest velocities are observed close to the continental shelves (Fahrbach et al., 1994). The Weddell Sea is dominated by five water masses distinguished on the basis of potential temperature $(\theta)$ and salinity (after Klatt et al., 2005). In the upper surface, the low salinity $(<34.6)$ Antarctic surface water (AASW) is found. As remnant of the preceding winter, a $\theta$ minimum marks the winter water (WW) layer at $\sim 100 \mathrm{~m}$ depth (Fig. 2a). Below the winter water, warm deep water (WDW) is found. The most voluminous water mass in the Weddell Sea is the slightly colder Weddell Sea Deep Water (WSDW, $-0.7^{\circ} \mathrm{C}<\theta<0{ }^{\circ} \mathrm{C}$ ) which is observed from $\sim 1500 \mathrm{~m}$ to $\sim 4000 \mathrm{~m}$ depth. The western part of the Weddell Sea is known as an important region for Weddell Sea 


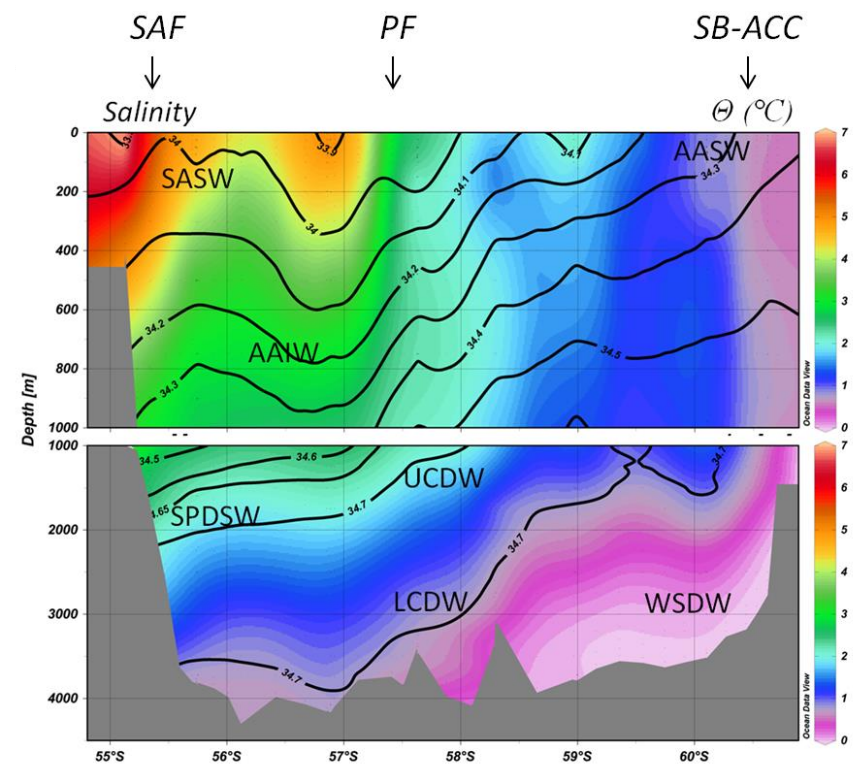

Fig. 2b. Potential temperature (color) and salinity (black contour lines) section of the Drake Passage transect. Approximate location of water masses and fronts (see text) is indicated.

Bottom Water (WSBW) $\left(\theta<-0.7^{\circ} \mathrm{C}\right)$ (Fig. 2a) (Huhn et al., 2008). Both WSBW and WDW influence the WSDW through overall vertical mixing. Eventually, a large part of the WSDW and WSBW leave the Weddell Sea and extend further Northwards as AABW (Klatt et al., 2005; Orsi et al., 1993; Garabato et al., 2002).

Due to the narrow extent of Drake Passage, the major Southern Ocean fronts are very close to each other. The Antarctic circumpolar current (ACC) approaches the continental shelves, and towards the south the subantarctic front (SAF), the polar front (PF) (defined as the northernmost extent of the $2{ }^{\circ} \mathrm{C}$ subsurface $\theta$ minimum Pollard et al., 2002) and the southern boundary of the ACC (SB-ACC) are found. Between the PF and the SAF, it is clearly visible that the colder, more saline water subducts as Antarctic intermediate water (AAIW) under warmer waters Fig. 2b). Sudre et al. (2011) distinguished the different water masses in the Drake Passage using multiparametric analysis. Briefly, south of the PF Antarctic surface water (AASW) was observed to a maximum depth of $\sim 100 \mathrm{~m}$. North of the PF, subantarctic surface water (SASW) reaches from the surface to a maximum of $700 \mathrm{~m}$ depth at the Patagonian side. Winter water (WW) was observed over most of the transect, at a depth of $200-300$ at $56^{\circ} \mathrm{S}$ to $\sim 100 \mathrm{~m}$ at $60^{\circ} \mathrm{S}$ (Fig. 2b). Antarctic intermediate water (AAIW) followed a downward path; from $300-600 \mathrm{~m}$ at the PF, to $800-1200 \mathrm{~m}$ depth at the Patagonian shelf (Fig. 2b). This pattern of water masses shoaling towards the south is also observed in the Circumpolar Waters below. The Upper Circumpolar Water (UCDW) and Lower Circumpolar Water (LCDW) were observed between $\sim 1200-2200 \mathrm{~m}$ and $\sim 2200-4000 \mathrm{~m}$, respectively, near the

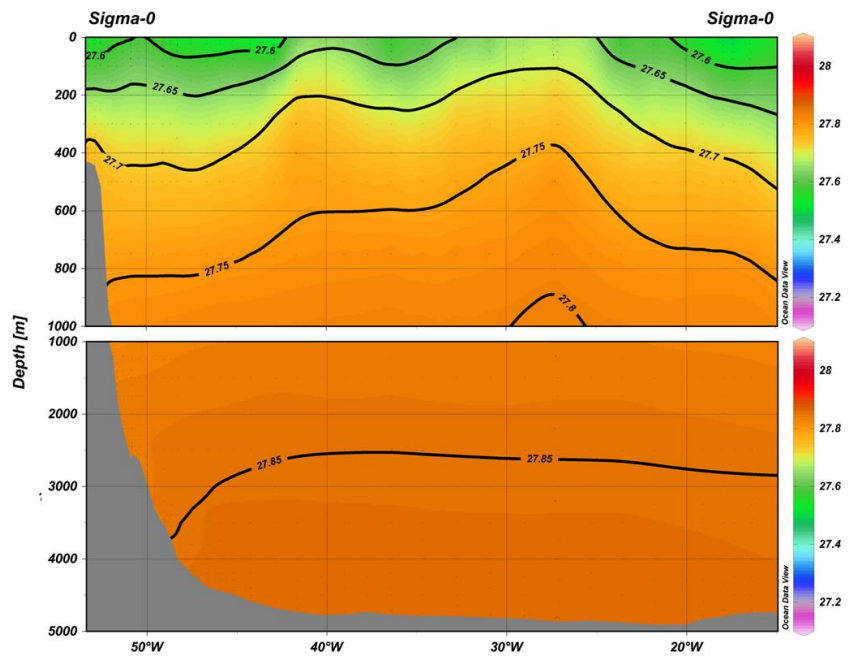

Fig. 3a. Section potential density (Sigma theta) vs. surface reference level (Sigma-0) of the of the Weddell Sea transect.

Patagonian Shelf, whereas to the south of the PF these water masses were observed at shallower depths between $\sim 150$ $700 \mathrm{~m}$ and $\sim 700-3000 \mathrm{~m}$, respectively. South of the PF, the WSDW was observed as a $500 \mathrm{~m}$ thick bottom layer (Fig. 2b). Close to the Patagonian shelf $\left(55-56.5^{\circ} \mathrm{S}\right)$, between $\sim 2000-3000 \mathrm{~m}$ depth Southeast Pacific Deep Slope Water (SPDSW) is present with elevated $\delta^{3} \mathrm{He}$ (Well et al., 2003; Sudre et al., 2011) and DMn (Middag et al., 2012), related to hydrothermal activity in the South Pacific source region of this water mass. The Drake Passage is known for the occurrence of mesoscale eddies. Locally, these eddies may be of major importance for the transport of trace elements, as reported for dissolved $\mathrm{Zn}$ (Croot et al., 2011) and iodate (Bluhm et al., 2011). The position of the fronts as well as the pattern of water masses, shoaling to the south, are clearly visible from the sigma-theta plot (Fig. 3b).

\section{Results}

The distribution of DFe in the Weddell Sea is depicted in Fig. 4a and b. Generally, the DFe concentrations within the Weddell Sea surface waters were very low, ranging from below the limit of detection $(\mathrm{LoD}=0.01 \mathrm{nM})$ to $0.1 \mathrm{nM}$. Exceptions to this pattern were slightly higher concentrations $(0.12-0.17 \mathrm{nM})$ in the upper surface $(10 \mathrm{~m}$ depth) at station 193 , and in the upper $50 \mathrm{~m}$ at station 210. Although there was little increase in DFe in the upper $100 \mathrm{~m}$ towards the Peninsula up to station 216 , concentrations showed a sudden increase between 200 and $600 \mathrm{~m}$ depth near the shelf break (station 216). In the southeast and northwest part of the Weddell Sea transect, concentrations in the WDW were $0.2-0.3 \mathrm{nM}$, whereas in the central Weddell Sea, even lower concentrations $(0.1-0.2 \mathrm{nM})$ were observed. Below the WDW, in the WSDW, concentrations started to increase with 


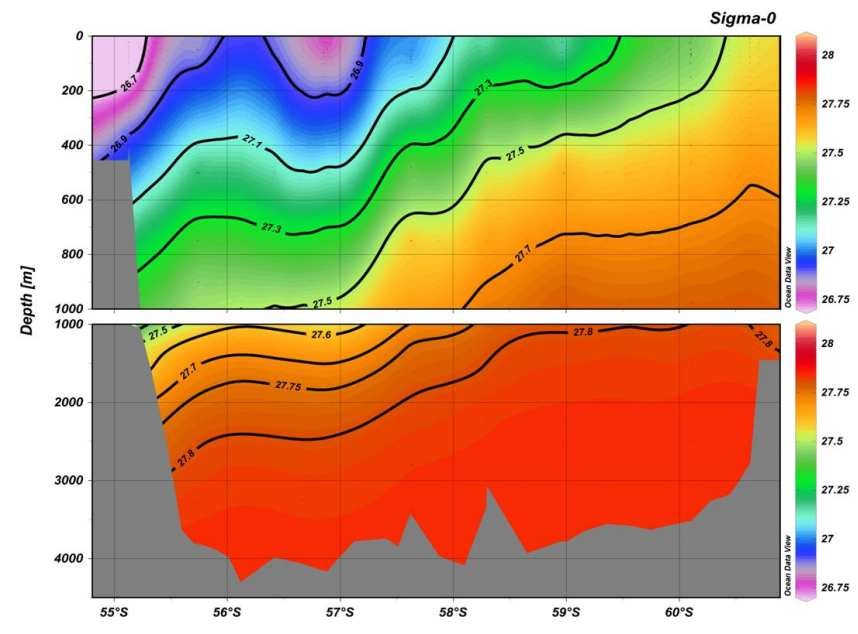

Fig. 3b. Section potential density (Sigma-theta) versus surface reference level (Sigma-0) of the of the Drake Passage transect.

increasing depth to values of $0.2-0.4 \mathrm{nM}$. The lowest concentrations in WSDW were observed in the centre of the Gyre, and slightly higher values towards the shelf. Concentration of DFe in the WSDW is relatively low compared to other deep water concentrations in the Southern Ocean (Klunder et al., 2011a; Tagliabue et al., 2012). Below $4000 \mathrm{~m}$, at most stations WSBW was observed, with slightly higher DFe concentrations, likely as a result of deep water formation along the shelf.

The distribution of DFe in the Drake Passage is depicted in Fig. 5a and b. In the Drake Passage, strong DFe fluctuations were observed in the surface waters. Close to the Peninsula, DFe concentrations reach $1-2 \mathrm{nM}$, with a maximum in the subsurface (100-200 m depth). Further north into Drake Passage, surface concentrations of DFe were low $(<0.2 \mathrm{nM})$, but an enrichment in DFe was observed at $58.3^{\circ} \mathrm{S}$ (station 238), corresponding to high $\mathrm{Al}$ concentrations (Middag et al., 2012). At the northern end of the transect, close to the South American Continent (Tierra de Fuego), a DFe enrichment corresponded with an enrichment of DMn and DAl and low salinities (Middag et al., 2012) and the highest DFe was observed above the Patagonian shelf $(2.64 \mathrm{nM})$ in the upper surface sample. In the deep Drake passage, the DFe increase with depth was stronger than observed in the Weddell Sea; concentrations $>0.25 \mathrm{nM}$ were observed deeper than 25$200 \mathrm{~m}$ in the Southern Drake Passage, and deeper than $400 \mathrm{~m}$ in the Northern Drake Passage (WW and AAIW, see Sect. 3). Deeper in the water column, relatively low DFe concentrations followed an ascending pattern towards the south, from $\sim 57.5^{\circ}-60^{\circ} \mathrm{S}$, as also observed in DMn and typical for the water mass distribution in the Drake Passage (Sect. 3). Over the Patagonian continental slope, a strong, local maximum in $\mathrm{DFe}(>1.5 \mathrm{nM})$ was observed at $\sim 2500 \mathrm{~m}$ depth in the SPDSW), that originates from the South Pacific and carries a hydrothermal signal (see Sect. 3; Middag et al., 2012; Sudre

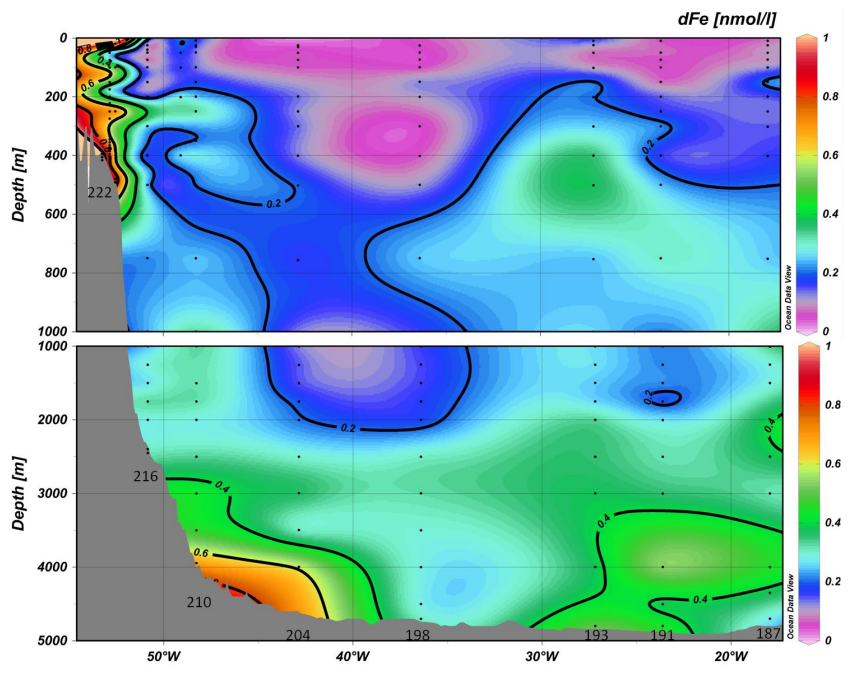

Fig. 4a. Section plot of DFe concentrations in the Weddell Sea transect; station numbers 187-216 along horizontal axis.

et al., 2011). The DFe data, along with physical and station information can be found in the online electronic supplement data Table S3.

The calculated nutrient removal (see Sect. 3.3 for details) for the Weddell Sea and Greenwich Meridian stations are shown in Fig. 6. There were strong fluctuations in the summer nutrient removal along both transects. Nevertheless, the stations along the Greenwich Meridian transect showed a decrease in the summer removal of nutrients towards the continent. Figure 6d shows the weighted average DFe concentration in the upper layer above the winter water - the upper layer from where nutrients were removed by biological uptake. Weighted average DFe was defined as the average of DFe concentrations corrected for the depth between two data points according to the trapezium rule. In the Weddell Sea, the following trend was observed; removal of nutrients increases Northwestwards until $\sim 64.5^{\circ} \mathrm{S}, 44.9^{\circ} \mathrm{W}$ followed by a sudden drop. For the Weddell Sea, removal of nutrients were consistent with previous findings of Hoppema et al. (2007) for data collected along the same transect in 1993. These authors also observed a sudden decrease in nutrient removal around $\sim 64.5^{\circ} \mathrm{S}$. Remarkably, for none of the stations in the Weddell Sea transect, a removal of DFe was observed; DFe values were uniform with depth until the winter water.

\section{Discussion}

\subsection{Comparison with other data in the region}

Dissolved Fe data of the open ocean in the central Weddell Gyre is scarce and mainly available for the surface waters of the near margin region. Recently reported $\mathrm{DFe}$ data are discussed in comparison to our results below. Sanudo-Wilhelmy et al. (2002) occupied a transect in the 


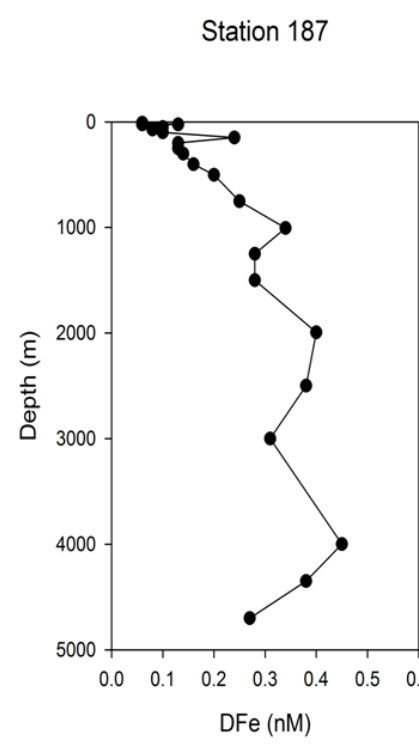

Station 204

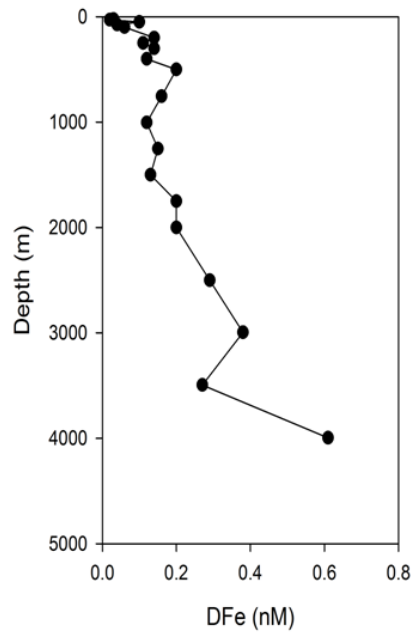

Station 191

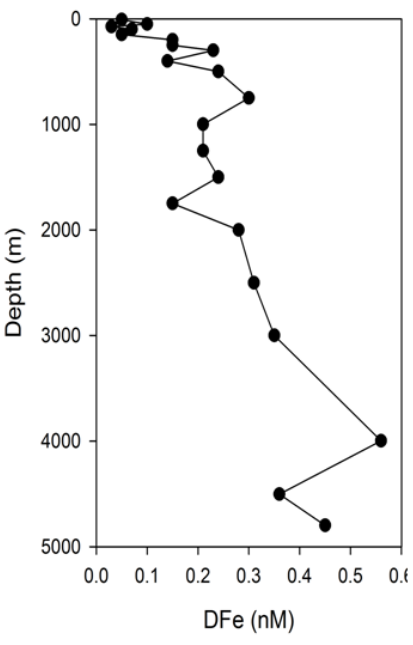

Station 210

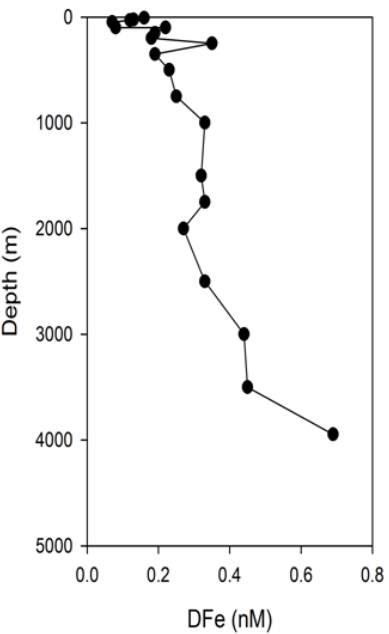

Station 193

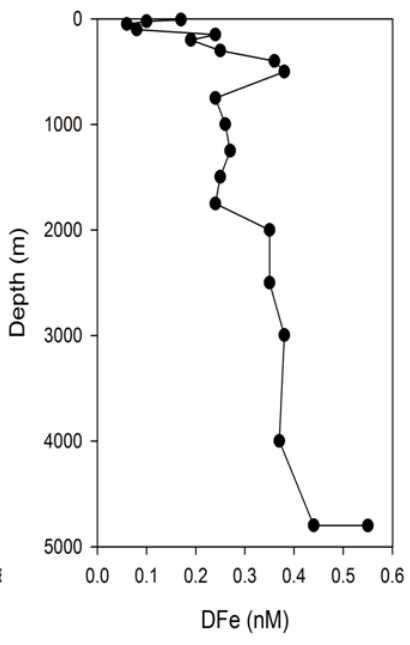

Station 216

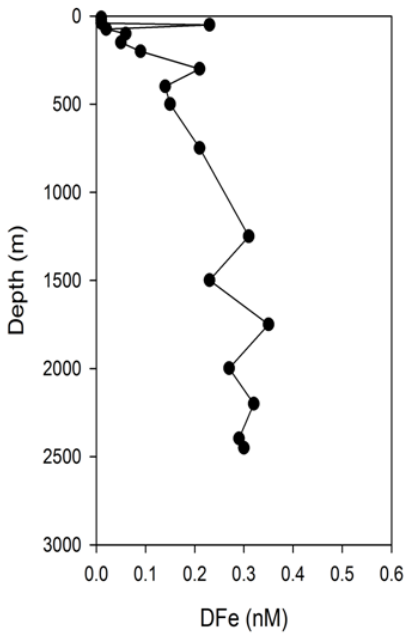

Station 198
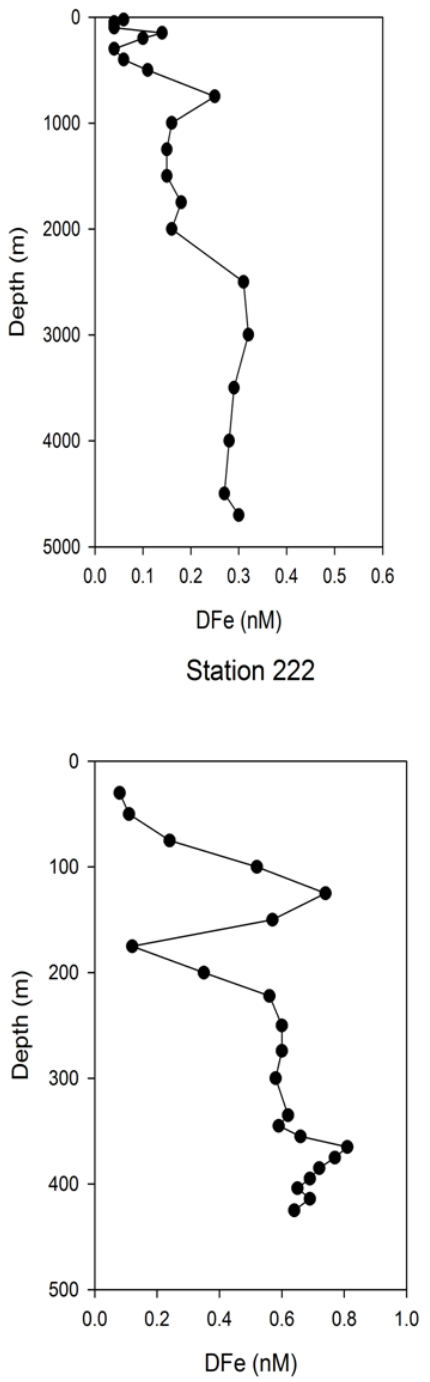

Fig. 4b. Vertical profiles of DFe at individual stations of the transect Weddell Sea. Note the different depth and concentration scale.

northwestern Weddell Sea, and reported surface DFe $(<1 \mathrm{~m}$ depth) concentrations in the range of $0.5-2 \mathrm{nM}$ for off-shelf stations. These reported values are significantly higher than the concentrations reported here, possibly due to the difference in depth; input of atmospheric dust or (surface) ice melt may increase DFe concentrations at the very surface layer. Recently, De Jong et al. (2011) reported DFe data at two stations; the first station was a station above the slope in the Weddell Sea. The DFe concentrations ranged from $0.6-0.9 \mathrm{nM}$ (upper $200 \mathrm{~m}$ ) to $1-3 \mathrm{nM}(200-1000 \mathrm{~m})$ and 5$20 \mathrm{nM}$ below $1200 \mathrm{~m}$ to the bottom $(1376 \mathrm{~m})$. These concentrations are significantly higher than the concentrations observed along our transect, particularly in the deep waters. However, their station was situated closer to the continent, above the continental slope, at $\sim 1350 \mathrm{~m}$ depth and therefore much stronger influenced by bottom sediment resuspension, as also indicated by the lowering of the light transmission signal (De Jong et al., 2011). Their other station was situated on the Scotia Ridge and showed relatively high DFe concentrations ( $\sim 3 \mathrm{nM}$ in upper mixed layer; $8-13 \mathrm{nM}$ between 100-750 m depth; $2-4 \mathrm{nM}$ between $1000-3000 \mathrm{~m}$ depth and $8-10 \mathrm{nM}$ from $3500 \mathrm{~m}$ to the bottom $(4200 \mathrm{~m})$. This station is situated on the Scotia Ridge and several water masses were observed that have been in contact with the bottom sediments, explaining the higher concentrations of DFe compared to our stations (De Jong et al., 2011). More DFe data in this region is primarily related to sea-ice/iceberg studies. Lannuzel et al. (2008) reported concentrations of $0.9-2 \mathrm{nM}$ in the upper $30 \mathrm{~m}$ in the western Weddell Sea, for a large part as a result of ice-melt. Lin et al. (2011) reported DFe 


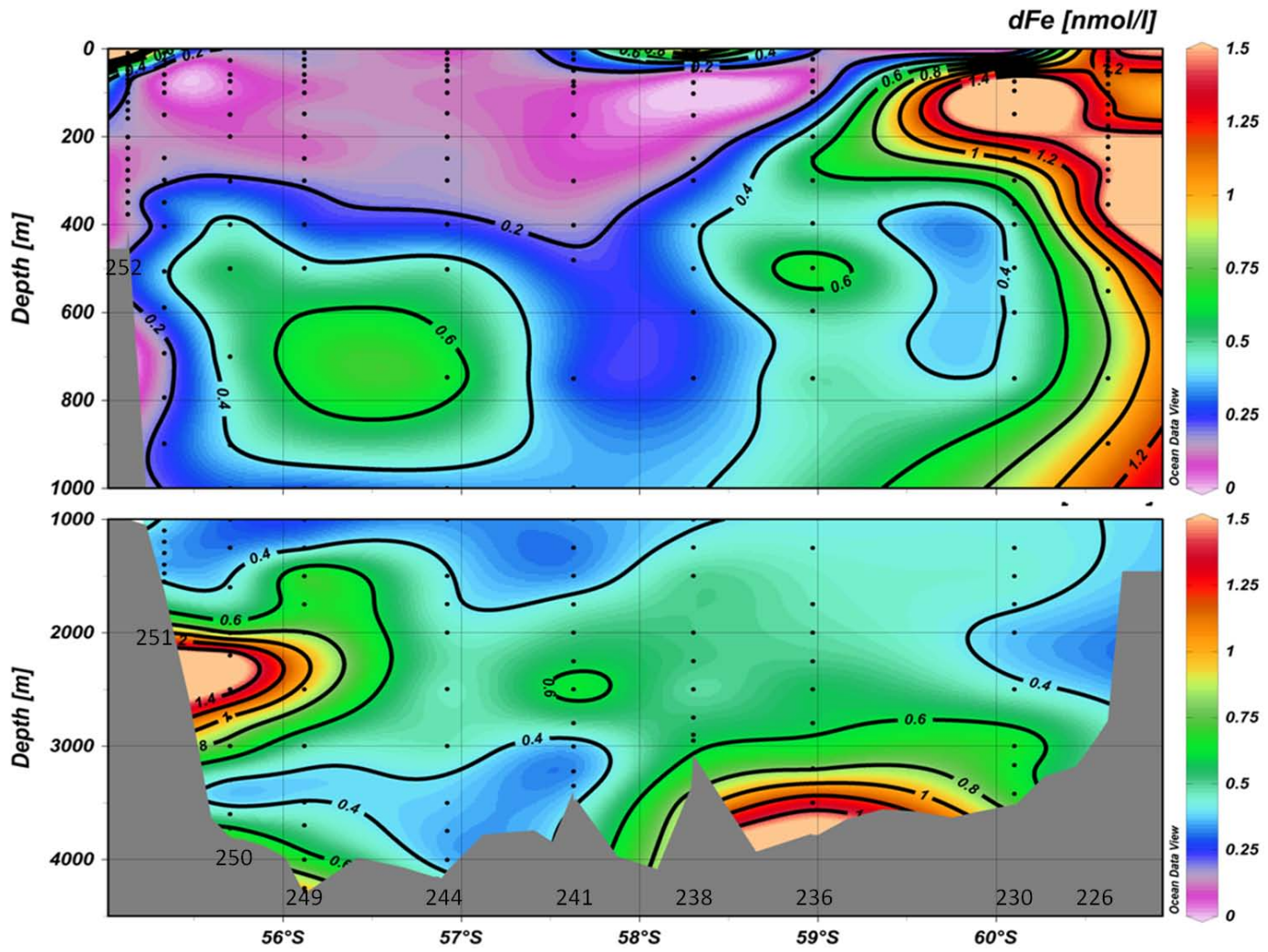

Fig. 5a. Section plot of DFe concentrations in the Drake Passage transect. station numbers 226-251 along horizontal axis.
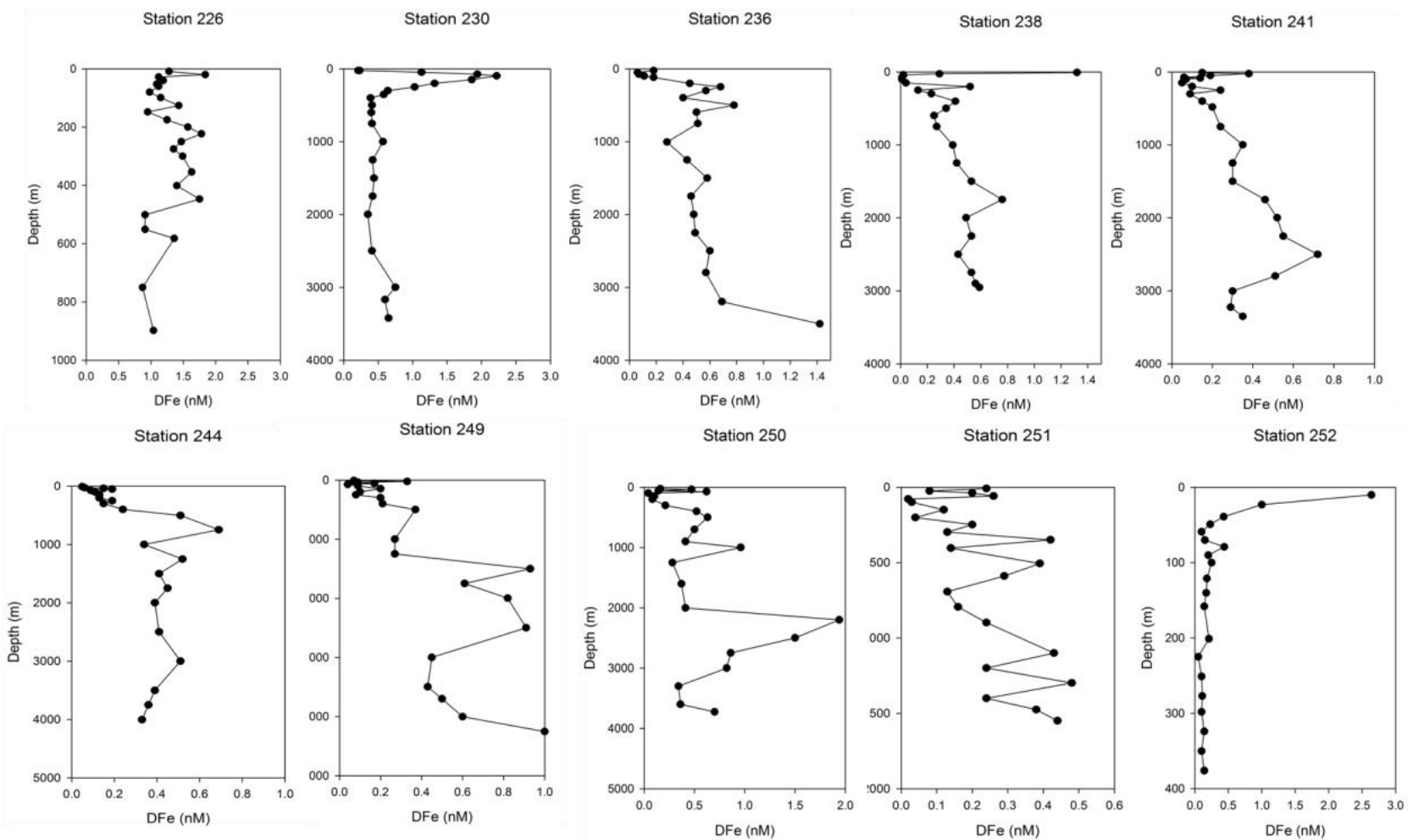

Fig. 5b. Vertical profiles of DFe at individual stations of the transect Drake Passage. Note the different depth and concentration scale. 

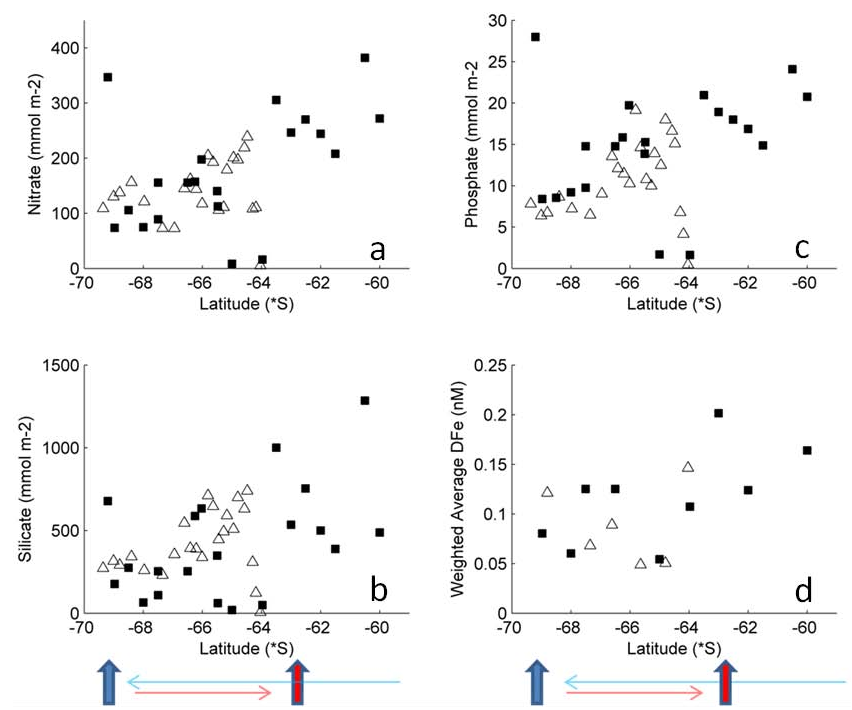

Fig. 6. Removal of nitrate (a), silicate (b), phosphate (c) and weighted average DFe (d) against latitude for the Weddell Sea transect (open triangles), and the Greenwich Meridian transect (filled squares) (Klunder et al., 2011a). Nutrients data is available for more stations than DFe data, hence more data points. Location of the shelf (500 $\mathrm{m}$ depth isobaths) is marked for the Greenwich Meridian transect (blue vertical arrow) and the Weddell Sea transect (red vertical arrow). Horizontal light arrows (blue and red) indicate the direction of the ship along the transect. (Please notice that the Greenwich Meridian transect is oriented north-south, and the Weddell transect is oriented from southeast to Northwest (see Fig. 1a)).

concentrations in the $1-2 \mathrm{nM}$ range for a cruise in the Powell Basin, in March 2009. These relatively high concentrations may be due to the fact that this cruise track was designed to study the effect of icebergs on DFe, and therefore may be biased towards areas with high concentrations. Moreover, the Powell Basin is situated downstream of the Peninsula, where shelf derived higher concentrations could be expected. Indeed, the 1-2 nM range is consistent with our stations 222 and 226 located close to the Peninsula. In the Drake Passage, Martin et al. (1990) reported a surface concentration of $0.16 \mathrm{nM}$, a minimum of $\sim 0.1 \mathrm{nM}$ at $100 \mathrm{~m}$ depth, followed by an increase to $0.4 \mathrm{nM}$ at $500 \mathrm{~m}$ depth and Ardelan et al. (2010) reported $\sim 0.2 \mathrm{nM}$ for ACC surface waters and $\sim 1.5-2.5 \mathrm{nM}$ for shelf waters, north of King George Island (data also used in Dulaiova et al., 2009). In an incubation study, Hopkinson et al. (2007) reported concentrations $\sim 0.1-0.14 \mathrm{nM}$ in the open ACC waters to $\sim 1.6-1.7 \mathrm{nM}$ for shelf waters. Our data roughly corresponded to these data, with low surface water concentrations $(<0.1 \mathrm{nM})$ and a DFe minimum at the subsurface in the ACC waters, and DFe concentrations of $\sim 2 \mathrm{nM}$ for shelf waters.

\subsection{Distribution of DFe in the Weddell Sea}

\subsubsection{Surface waters in the Weddell Sea}

The very low surface DFe ( $<$ LoD $(10 \mathrm{pM})$ to $100 \mathrm{pM})$ concentration over most of the Weddell Sea transect indicated a strong (seasonal) depletion of DFe. The significant vertical advection reported for the Weddell Sea (Weppernig et al., 1996; Haine et al., 2008; De Jong et al., 2012) indicated that upwelling from deeper waters is an important source of $\mathrm{DFe}$ to the Weddell Sea surface. Moreover, in our study region, melting of floating icebergs (mainly in the Weddell Sea) and sediment derived Fe are important sources, as confirmed by modelling studies (Lancelot et al., 2009) and fieldwork (Dulaiova et al., 2009; Ardelan et al., 2010; Lin et al., 2010). However, this is mainly restricted to the region along the Antarctic Peninsula and less relevant for the central Weddell Basin (Middag et al., 2012). The Weddell Sea and Scotia Sea are accumulation regions for icebergs (Stuart and Long, 2011) and DFe enrichment due to icebergs has been reported (Lin et al., 2011), mainly along what is colloquially known as "iceberg alley" along the northern perimeter of the Weddell Sea. Lannuzel et al. (2008) reported high ( $\sim 1 \mathrm{nM}) \mathrm{DFe}$ concentrations upon the melting of seasonal sea ice in the Weddell Sea. However, these concentrations were reported in November-December, at the spring time of sea-ice melt. During our occupation of the transect, in March 2008, any DFe derived from significant sea ice earlier in the season, would likely already have been taken up by phytoplankton. Possible effects of melting sea ice or icebergs on the distribution of DFe would have been reflected in low salinity. Almost all of the upper $25 \mathrm{~m} \mathrm{DFe}$ values were $<0.1 \mathrm{nM}$, and salinities were high $(>34)$. However, at station 210 a small enrichment was observed $(\mathrm{DFe}=0.16 \mathrm{nM})$ at $10 \mathrm{~m}$ depth corresponding to a slightly lower salinity (33.8) (Figs. 2a and 4a). This could have been caused by a small amount of sea-ice melt water. Deposition of dust is very limited in the Weddell Sea and therefore plays a minor role in this region (Duce et al., 1991; Jickells et al., 2001; Cassar et al., 2005). Nevertheless, over time, aerosols may accumulate on sea ice or on the Antarctic continental ice sheet, and deliver (D)Fe to the Weddell Sea water upon melting of this sea ice.

\subsubsection{DFe distribution and biological uptake}

A significant relationship of dissolved $\mathrm{Mn}$ with nutrients $\left(\mathrm{PO}_{4}, \mathrm{NO}_{3}\right.$ and $\mathrm{Si}$ ) and (inverse) with chlorophyll fluorescence indicates biological depletion of $\mathrm{Mn}$ from the surface waters of this transect (Middag et al., 2013). No correlation was found for DFe and major nutrients $\left(R^{2}<0.1\right)$ in the upper $100 \mathrm{~m}$ of the Weddell Sea. This may have been caused by the complex pattern and seasonality in sources as well as by biological uptake and ligand binding and non-biological scavenging of DFe. Some data is available to quantify some of these processes. For example, ${ }^{234} \mathrm{Th} /{ }^{238} \mathrm{U}$ disequilibrium 
data obtained by Rutgers van der Loeff et al. (2011) resulted in POC export estimates for the same transect, although not always sampled at the same stations. However, there are many factors that influence the phytoplankton growth in the region, such as irradiance, depth of the mixed layer, grazing and nutrient availability (Boyd, 2002; Wright et al., 2010) and there are differences in physical conditions (determining vertical and horizontal mixing). These uncertainties, combined with the relatively small differences in DFe inventory at the different locations compared to the accuracy of the measurements, make it difficult to related the distribution of DFe to the local biological uptake and export.

\subsubsection{Seasonal removal of DFe and nutrients from surface waters}

A continuous input of DFe from the Antarctic shelf region stimulating production and thus nutrient removal in the near margin region, as supposed by Hoppema et al. (2007), would have been reflected in the relationship between DFe and the nutrient removal values. However, we did not observe a trend in DFe removal in the Weddell Sea (although we did not trace WW (thus determine DFe removal) close to the margin). The clarity of the relationship between $\mathrm{DFe}$ and the nutrient removal values will decrease depending on the DFe concentrations; if DFe is in large excess, a relationship with nutrient removal may not be identified. Figure $7 \mathrm{a}-\mathrm{f}$ shows the nutrient depletion, for both transects relative to the amount of $\mathrm{DFe}$ present in the water above the winter water layer (weighted average). It is important to note, however, that the nutrient removal estimates represent a time-integrated signal over spring and summer, whereas the reported DFe concentration is a snap-shot in time at the moment of sampling. For DFe no removal could be calculated as there was no discernible concentration difference between the WW and the overlying AASW (see Sect. 3). It appears that the regions with a strong nutrient removal did indeed have high DFe concentrations, although this was mainly seen in the stations along the Greenwich meridian, which may partially reflect a difference in DFe input between the central Weddell Gyre and Greenwich Meridian region. Two stations in the west along the Weddell Sea transect (station 198 and 204) showed a relatively strong nutrient removal in accordance with earlier findings in this region (Hoppema et al., 2007), despite low DFe concentrations. This may be explained by growth and export of phytoplankton earlier in the season, which would be consistent with the very high values for POC export observed in the region of station 204. Around station 198, no sample for POC export has been taken, but the fluorescence signal is high (CTD technician, personal communication). Likely, concentrations of DFe were high enough to stimulate primary production in the period prior to sampling. The high DFe despite low nutrient removal that is observed in station 210 may have been attributed to the recent ice melt (see Sect. 6.1), which would not yet have been reflected in the nutrient drawdown.

The pattern of removal ratio (the ratio of nutrients removed from the upper water layer above the WW, as described above) for a particular station could be compared to the sea water ratio (ratio of nutrients present in the upper layer in the seawater). In case of a steady state (no additional sources or sinks besides biological removal) this should result in a reverse pattern in the seawater compared to the removal ratios. The ratio of $\mathrm{N}: \mathrm{P}$ and $\mathrm{N}: \mathrm{Si}$ in seawater is also influenced by other processes than DFe supply; mainly by continental shelf related processes, such as inflow of surface water influenced by bottom water, or influenced by shelf particles, at the edge of the transect. Nevertheless, the influence of $\mathrm{DFe}$ on the $\mathrm{N}: \mathrm{P}$ and $\mathrm{N}$ : Si removal ratios is visible in the seawater ratios. From Fig. 8 it appears that the slightly higher $\mathrm{N}: \mathrm{P}$ and $\mathrm{N}$ : Si seawater ratios (indicating low removal of $\mathrm{N}$ relative to $\mathrm{P}$ and $\mathrm{Si}$ ) in the central Gyre at around $\sim 35-40^{\circ} \mathrm{W}$ were consistent with where the lowest $\mathrm{Fe}$ concentrations were observed. This is what one would expect as low DFe has been shown to give low $\mathrm{N}$ : Si and N : P ratios in plankton (De Baar et al., 1997).

Figure $7 \mathrm{~d}$ shows the estimated nutrient removal ratios (the ratio of removal of one element and removal of the other element) relative to the weighted average $\mathrm{DFe}$, and generally shows the lowest $(<0.4) \mathrm{N}$ : Si removal ratio at lower $\mathrm{DFe}$ $(<0.1 \mathrm{nM})$ concentrations and the highest $\mathrm{N}:$ Si removal ratios $(>0.4)$ at $\mathrm{DFe}>0.1 \mathrm{nM}$ concentrations, although this is clear for the Weddell Sea stations, and less so much for the zero meridian Transect. This is consistent with the seawater ratios along most of the transect (see below) and previous observations showing low $\mathrm{N}: \mathrm{P}$ and $\mathrm{N}$ : Si uptake in iron limited systems (De Baar et al., 1997; Marchetti and Cassar, 2009).

Regarding P : Si (Fig. 7e) and N : P (Fig. 7f) removal ratios, the results were not so straightforward. There was a tendency of increasing $\mathrm{N}: \mathrm{P}$ removal ratios (from $\sim 5$ to $\sim 15$ ) with increasing DFe, but this was only visible for the Greenwich Meridian stations. The Weddell Sea stations showed a relatively constant $\mathrm{N}: \mathrm{P}$ removal ratio $(\sim 13)$ with $\mathrm{DFe}$, possibly related to phytoplankton size (see Sect. 6.2.2.3 below).

In general, the nutrient removal ratios were consistent with the seawater ratios (ratio of remaining nutrients). For example, a higher $\mathrm{N}$ : Si removal ratio (0.8) was found at station $210\left(\sim 48.3^{\circ} \mathrm{W}\right)($ Fig. $7 \mathrm{~d})$, where a lower N:Si ratio in the seawater was observed (Fig. 8a). Towards both ends of the section, near the Antarctic continent and the Peninsula (Fig. 8a), a change in seawater nutrient ratios was observed. However, the somewhat higher $\mathrm{N}: \mathrm{Si}$ removal ratio at station $187\left(\sim 17.9^{\circ} \mathrm{W}\right)$ does not match up with the seawater ratio, and is likely explained by the sea-ice coverage and related nutrient dynamics of the melting and formation of sea ice (Vancoppenolle et al., 2010) from the months before the cruise until the time of sampling. Also, around $\sim 20^{\circ} \mathrm{W}$, clearly a distinct water mass was found as seen from its physical parameters (Fig. 2a and 3a). This was the strong flowing 
westward branch of the Weddell Gyre (Fahrbach et al, 2011). Apparently, the water mass origin had a stronger influence on the relative nutrient concentrations than local processes. Indeed, nutrient concentrations in the region around $\sim 20^{\circ} \mathrm{W}$ were consistent with those in the westward branch of the Weddell Gyre at the zero meridian transect (Klunder et al., 2011a). Unlike the $\mathrm{N}: \mathrm{Si}$ removal ratio, the higher $\mathrm{N}: \mathrm{P}$ removal ratio (20.5) observed at station 187 , was consistent with a lower $\mathrm{N}$ : $\mathrm{P}$ seawater ratio (Fig. 8b).

\subsubsection{Relation between DFe, nutrient removal and size of diatom species}

The difference in nutrient uptake ratios between the Greenwich Meridian and central Weddell Gyre might be explained by a difference in phytoplankton size. The available data from the ANT XXII/2 cruise allowed us to investigate this relation, and (carefully) make some predictions on the relation between these parameters. For clarity, the size and the composition of the phytoplankton community in the concerning stations are included as electronic supplementary information (Table S1 and S2). According to satellite observations, in 1997-2006 diatoms and nanoeukaryotes were the dominant groups in the Southern Ocean, in any case during and preceding the same time of year as our cruise (Alvain et al., 2008). Our study regions were dominated by diatoms (Alderkamp et al., 2010; Neven et al., 2011), and in the central Weddell Sea stations the size of the diatoms is generally somewhat smaller (Table S1, S2, Neven et al., 2011). From the same expedition, specific counts and measurements of the phytoplankton community are available for stations at the Greenwich Meridian (150, 161, 167 and 178) and for stations in the Eastern Weddell Gyre (191, 193, 198, 204 and 210), see Fig. 1a. The composition of the diatom community in both regions was not significantly different between both regions at time of sampling (Table S2). It should be noted that this is not necessarily the case for the (complete) time of uptake. Assuming no significant changes in the composition of the diatom community, here we used estimations of the size of the diatoms present in both regions. On average diatoms were significantly smaller in terms of biovolume (one sided homeoscedastic $t$ test, $p<0.1$ ) in the Eastern Weddell Sea region (average $4258 \pm 1883 \mu \mathrm{m}^{3}$ ) than at the Greenwich Meridian (average $6981 \pm 2397 \mu \mathrm{m}^{3}$ ) (Table 1 (raw data in Table S2)). Moreover, there was a larger proportion of smaller $\left(<1000 \mu \mathrm{m}^{3}\right)$ diatoms ( $7 \%$ and $3 \%$ of total respectively) and a lower proportion of large diatoms $\left(>5000 \mu \mathrm{m}^{3}\right)(70 \%$ and $84 \%$ of total respectively) in the eastern Weddell region compared to the Greenwich Meridian (Table 1). There are two mechanisms via which the $\mathrm{N}: \mathrm{P}$ uptake ratio of diatoms is influenced by their size. First, the specific growth rate of diatoms with regard to $\mathrm{Fe}$ is dependent on their surface to volume (S/V) ratio (Sarthou et al., 2005; De Baar et al., 2005). Smaller diatoms generally have a larger $\mathrm{S} / \mathrm{V}$ ratio which is beneficial for their Fe uptake (see
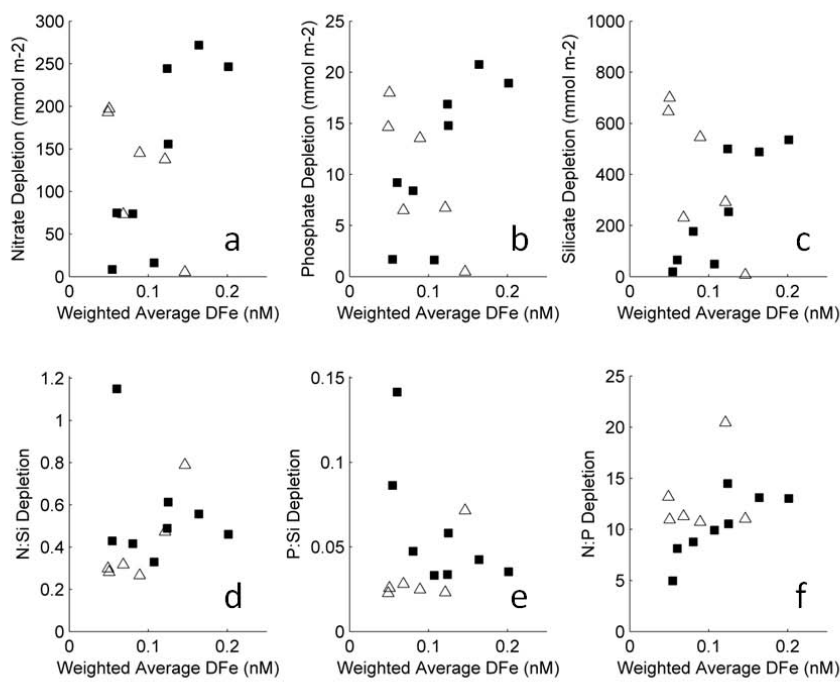

Fig. 7. Removal of nitrate (a), silicate (b), phosphate (c) and the removal ratios of $\mathrm{N}: \mathrm{Si}(\mathbf{d}), \mathrm{P}: \mathrm{Si}(\mathbf{e})$ and $\mathrm{N}: \mathrm{P}(\mathbf{f})$ vs the weighted average DFe concentrations for the Weddell Sea transect (open triangles), and the Greenwich Meridian transect (filled squares) (Klunder et al., 2011a).

also Timmermans et al., 2004). Additionally, smaller cells have a smaller diffusive boundary layer thickness, which increases the flux from the seawater into the cell (Marchetti and Cassar, 2009). Therefore, impairment of $\mathrm{N}$ uptake as a result of Fe limitation (De Baar et al., 1997) is more likely to occur in larger species, as observed in the Greenwich Meridian stations. Also the uptake kinetics of nitrogen depends on the $\mathrm{S} / \mathrm{V}$ ratio, whereas such a relation is not found for $\mathrm{P}$ uptake (Sarthou et al., 2005). Our findings of low N : P removal ratios at low DFe in the Greenwich Meridian stations and the absence of a low $\mathrm{N}: \mathrm{P}$ removal ratio in the central Weddell Gyre match the findings of Timmermans et al. (2004). They observed that the largest species (small S/V ratio) showed the strongest effect of Fe depletion in their N : P uptake; and this effect became less with smaller species. Given the observed differences in the nutrient uptake between both regions, and the clear differences in size, we propose a possible relation between both parameters.

The above postulated hypothesis is consistent with observations made during the EIFEX in situ iron fertilization experiment. In this experiment, Hoffmann et al. (2006) found that the large $(>20 \mu \mathrm{m})$ size class of phytoplankton (comprising large diatoms) at low ambient dissolved $\mathrm{Fe}$, had a cellular $\mathrm{N}$ : $\mathrm{P}$ ratio of $\sim 5$. Upon DFe enrichment this increased to $\sim 15-16$. Such differences were absent for the smaller $(<20 \mu \mathrm{m})$ size classes. The diatom size classes in the latter study are comparable to the median size of diatoms of 20-25 $\mu \mathrm{m}$ observed in our study. Based on this, we suggest that, the N:Si and N:P uptake ratios may indicate an important (possibly limiting) role for DFe on phytoplankton abundance, community composition and the uptake and cycling of 


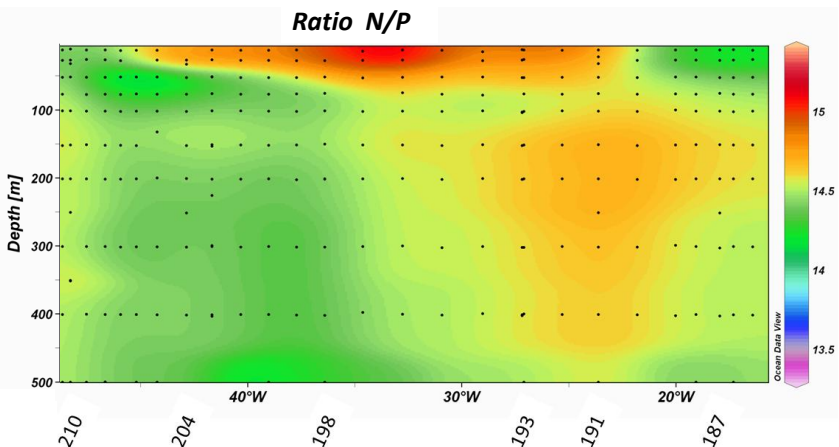

Fig. 8a. Section plot of $\mathrm{N}$ : $\mathrm{P}$ ratio along the Weddell Sea transect in the upper $500 \mathrm{~m}$, for that region where a winter water Layer is observed and a removal ratio is calculated $\left(\sim 17-\sim 48.5^{\circ} \mathrm{W}\right)$. The locations of the stations where DFe data is available and a nutrient removal is calculated are presented.

nutrients in the Weddell Gyre along both transects (Greenwich Meridian and Weddell Sea). It should be noted here that the DFe concentrations in the surface waters along the transect are low $(<0.25 \mathrm{nM})$ compared to the concentrations in the enrichment treatments of the experiments mentioned above (Timmermans et al., 2001; Hoffmann et al., 2006). This may influence the relative effects of DFe availability that are expected to be lower in our field situation compared to the abovementioned studies.

\subsubsection{Deep waters in the Weddell Sea}

In the deep waters of the Weddell Sea the dissolved Fe concentrations were very low, but gradually increased with depth. Dissolved Fe in the deep water masses of the Weddell Sea was low compared to that north of the Weddell Basin, and also relative to deep water concentrations observed worldwide (Moore and Braucher, 2008). Following the properties derived by Klatt et al. (2005) (see Sect. 4), we could calculate the average DFe in the different water masses of the Weddell Sea; the concentration was $0.21 \pm 0.08(n=52)$ in WDW, $0.32 \pm 0.12(n=42)$ in WSDW and $0.35 \pm 0.10$ $(n=11)$ in WSBW (overall mean for the deep water masses $0.27 \pm 0.12 \mathrm{nM}$ ). In comparison, Klunder et al. (2011a) reported concentrations for the Weddell Gyre deep water masses along the Greenwich Meridian of $0.33 \pm 0.14 \mathrm{nM}$ (WDW, WSDW, WSBW) in the westward flowing southernmost limb of the Weddell Gyre, and $0.47 \mathrm{nM} \pm 0.16 \mathrm{nM}$ in the, more northern, eastward flowing limb. As expected, the concentrations here observed were similar, but slightly lower than those observed in the westward flowing component at the Greenwich Meridian. As these were the same water masses, apparently some DFe was lost due to scavenging removal during transit from the Greenwich Meridian to the Weddell Sea. Conversely, there was a large difference in DFe concentration between the Weddell Sea transect deep waters and the eastward limb of the Weddell Gyre at the Greenwich

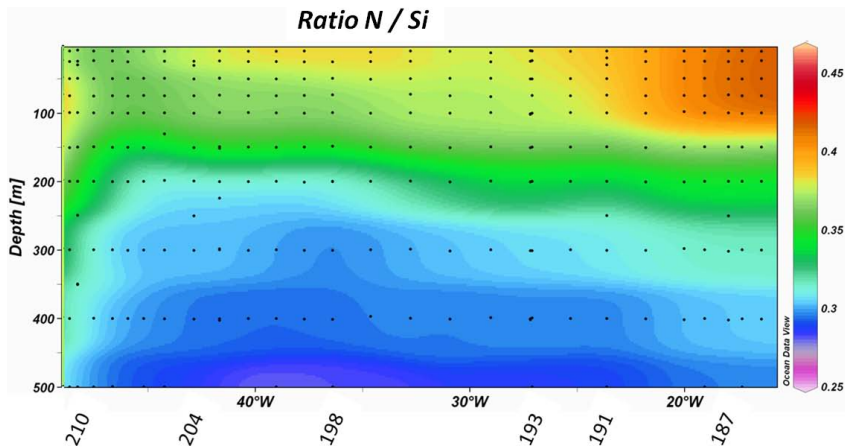

Fig. 8b. Section plot of $\mathrm{N}$ : Si ratio along the Weddell Sea transect in the upper $500 \mathrm{~m}$, for that region where a winter water Layer is observed and a removal ratio is calculated $\left(\sim 17-\sim 48.5^{\circ} \mathrm{W}\right)$. The locations of the stations where DFe data is available and a nutrient removal is calculated are presented.

Meridian. This indicated that on its way eastwards, there must have been significant input of DFe to the deep waters at the south Scotia Ridge. These sources could have been either sediment resuspension or a DFe flux from the sediment at the south Scotia Ridge and/or inflow of relatively high DFe circumpolar deep waters in the $45-55^{\circ} \mathrm{S}$ region as observed by Matano et al. (2002). Also hydrothermal input from the south Scotia Ridge is an important Fe input source (Klinkhammer et al., 2001). Moreover, there are indications of hydrothermal iron input close to the Greenwich Meridian, at the Scotia Ridge (Klunder et al., 2011a). The deep water masses that leave the Weddell Sea, form the AABW flowing into the ACC and the abyssal world oceans (Naviera Garabato et al., 2002; Hoppema et al., 2010). The here reported DFe concentrations of $\sim 0.32 \pm 0.12 \mathrm{nM}$ for WSDW and $0.35 \pm 0.10 \mathrm{nM}$ for the WSBW, thus eventually for the AABW, were on the lower end of the wide range of DFe concentrations observed in AABW throughout the Atlantic Ocean; $\sim 0.3 \mathrm{nM}$ (Klunder et al., 2011a), 0.38-0.8 nM (Chever et al., 2010b) and $0.28-0.93 \mathrm{nM}$ (Rijkenberg et al., 2011) for the South Atlantic and $0.7-0.8 \mathrm{nM}$ (Laës et al., 2003), $0.7 \mathrm{nM}$ (Thuroczy et al., 2010), 0.36-0.92 nM (Rijkenberg et al., 2011a, b) for the North Atlantic. This suggested DFe enrichment of AABW, likely by mixing with overlying Fe-rich NADW as well as supply from underlying sediment on its way northwards.

Downslope convection of surface waters close to the Peninsula, along the slope, renewing WSBW has been observed in the Weddell Sea (Hoppema et al., 2010). The downslope convection is also visible in the $\theta$ sections of our cruise (Fig. 3). Moreover, recently observed maxima in dissolved barium (Hoppema et al., 2010), iodate and CFC-12 (Bluhm et al., 2011) as well as DAl and DMn (Middag et al., 2013) in the WSBW, indicate such downslope movement of dense shelf waters. No large influence of downslope convection was observed in the distribution of DFe: little enrichment was observed at $\sim 51^{\circ} \mathrm{W}$ (station 216 ), 

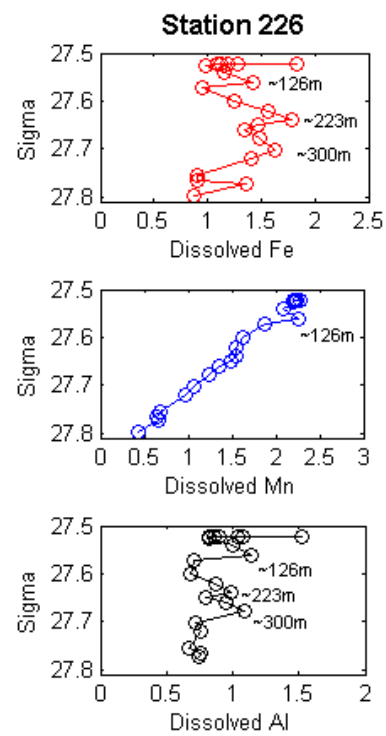
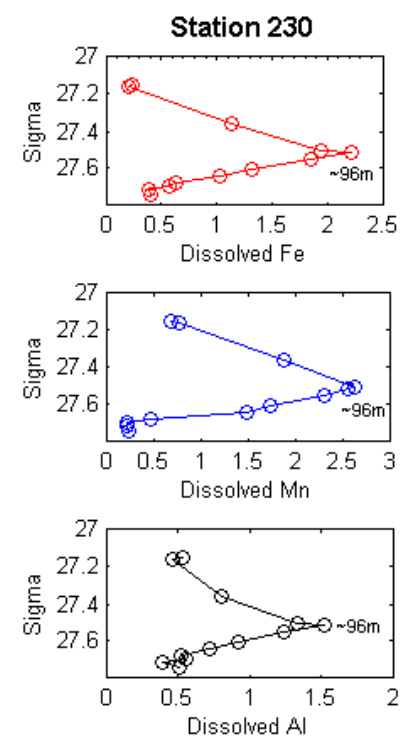
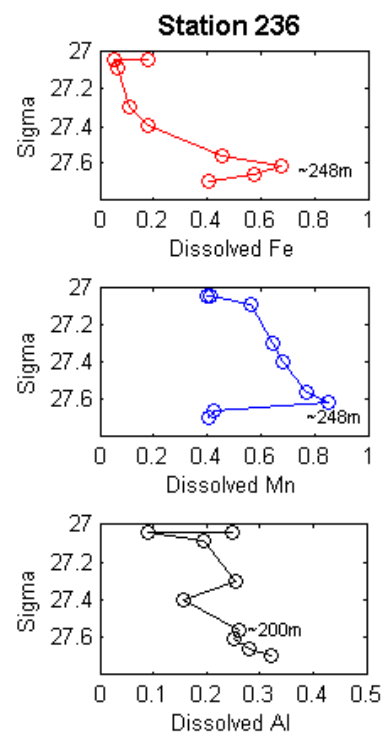

Fig. 9. Sigma theta $(\sigma \theta)$ vs. Dissolved Fe, Dissolved Mn (Middag et al., 2012) and Dissolved Al (Middag et al., 2012) (nM) for the stations adjacent to Elephant Island (see Fig. 1b). Note the different metal concentration scales for different stations. Also corresponding depths of peak values are shown.

$2500 \mathrm{~m}$ depth, despite indications of shelf water input (low $\theta$, not shown) and higher DMn (Middag et al., 2013). However, in the deep basin, some enrichment of DFe was observed associated with low $\theta$, indicating that DFe enrichment of WSBW due to downslope convection could occur. Unlike dissolved Ba (Hoppema et al., 2010), the DFe delivered by this process to the WSBW appeared insufficient to significantly enhance the DFe concentration in the overlying WSDW by upward mixing.

\subsection{Distributions of Fe in Drake Passage}

\subsubsection{Surface and sub-surface waters in Drake Passage}

During our cruise, we observed an input of DFe from the shelves around Elephant Island into the Drake Passage. This was consistent with earlier findings for DFe (e.g. Dulaiova et al., 2009), and also matched with DMn and DAl concentrations from the same stations (Fig. 9; Middag et al., 2012). Above the shelf (station 226), high DFe concentrations were observed at the potential density (sigma theta, $\sigma_{\theta}$ ) isopycnals of $27.5(1.87 \mathrm{nM}), 27.55(1.5 \mathrm{nM})$ and $~ 27.64(1.8 \mathrm{nM})$. The first two maxima were also observed, as a broad peak, at station 230 further into Drake Passage. Unfortunately there were no samples at this $\sigma_{\theta}$ level at station 236 (Fig. 9) even further offshore. Remarkably, the peak at $\sigma_{\theta} 27.64$ was observed as a small peak at station 226 but not further offshore at station 230 yet it appeared again at station 236. This illustrates that the many dynamic small gyre like structures observed to the north of Elephant Island (Ardelan et al., 2010; their Fig. 10; Hewes et al., 2009) may cause a complex pattern of off-shelf currents in this region. The input of
DFe from the Antarctic Peninsula shelf north of Elephant Island is in line with findings from Ardelan et al. (2010), who observed a DFe enrichment at $\sigma_{\theta}=27.5-27.6$. Moreover, Charette et al. (2011) reported a maximum concentration of radium $(\mathrm{Ra})$ values at $\sigma_{\theta}=27.5-27.6$ for this region, indicating shelf-derived waters. Despite the low number of stations, we estimated the scale length (distance where the DFe concentration is $1 / \mathrm{e}$ of the initial concentration) at $\sim 200 \mathrm{~km}$. This is reasonably similar to the scale length for DFe observed for shelf input in the Nansen Basin, Arctic Ocean $((\sim 263 \mathrm{~km})$; Klunder et al., 2011b). Similar to the Drake Passage (Renault et al., 2011), in the Nansen Basin the direction of the shelf current is also perpendicular to the shelf (Klunder et al., 2011b) resulting in a relatively shortscale length compared to other regions (Johnson et al., 1997). In our study region, Nielsdottir et al. (2012) reported a scale length on the same order, $\sim 102 \mathrm{~km}$, for transects off South Georgia Island and Bird Island. The scale length of $\sim 200 \mathrm{~km}$ is considerably higher than the $\sim 25 \mathrm{~km}$ reported by Ardelan et al. (2010) for the same region. This may partially be explained by the fact that latter scale length was calculated for the upper $\sim 50 \mathrm{~m}$, rather than the subsurface maximum as used in this study. This would indicate more rapid removal of $\mathrm{Fe}$ from the upper $50 \mathrm{~m}$ compared to the subsurface maximum, most likely due to biological uptake. Moreover, the strong eastward velocities of the ACC, turn the shelf region into a source of DFe for regions further East, supporting the more intense summer plankton blooms in the Scotia Sea (Borrione and Schlitzer, 2010).

Further into the Drake Passage, at $\sim 350 \mathrm{~km}$ from the shelf (station 238), a visible DFe enrichment was found in the 
subsurface waters (indicating this is shelf derived water), below a low DFe upper layer of $150 \mathrm{~m}$, which, in the northern part of the Drake Passage, extended to $\sim 500 \mathrm{~m}$ depth (Fig. 2b). The DFe $=0.2 \mathrm{nM}$ contour (Fig. 5b) approximately coincided with the 34.2 isohaline and with the surface and subsurface water masses (SASW, AASW and WW) as classified by Sudre et al. (2011) for this region. Maximum primary production in the Drake Passage is observed in the December - February period (Moore and Abbott, 2001). Biological removal of DFe from the surface waters and subsequent downwards transport may have caused the sharp difference in DFe concentrations between these surface waters and the deeper circumpolar deep waters (Fig. 5a). Moreover, given the strong geostrophic velocities for the surface waters of our transect $\left(0.1-0.4 \mathrm{~m} \mathrm{~s}^{-1}\right.$ at $100 \mathrm{~m}$ depth; Renault et al., 2011) these (sub)surface waters originated (mostly) from the South Pacific Ocean. This provides an additional explanation for the low surface DFe concentrations in Drake Passage as these waters from the Pacific Sector of the Southern Ocean are known to be low in DFe $(\sim 0.05 \mathrm{nM}$ in the 100 $120^{\circ} \mathrm{W}$ region in January/February (Gerringa et al., 2012) and $\sim 0.2 \mathrm{nM}$ at $120^{\circ} \mathrm{W}$ in March/April De Baar et al., 1999), due to biological removal or lack of input sources (De Baar et al., 1999; Hiscock et al., 2001).

An exception to the generally low concentration of DFe was the relatively high $\mathrm{DFe}$ concentration observed in the uppermost water column at station 238. A concentration of $1.32 \mathrm{nM}$ and $0.29 \mathrm{nM}$ at 10 and $25 \mathrm{~m}$ depth, respectively, was underlain by DFe depleted waters $(<0.06 \mathrm{nM})$ to $200 \mathrm{~m}$ depth. This surface maximum showed good correspondence with high dissolved $\mathrm{Al}$ concentrations at the same depths (Middag et al., 2012). Five day HYSPLIT (HYbrid SingleParticle Lagrangian Integrated Trajectory) backwards trajectory (Fig. S1) confirmed that the air above this region originates from Patagonia. The nearby station 241 did not show an upper surface maximum despite air originating from Patagonia, which may be explained by lack of precipitation. Shipboard data showed that in the $24 \mathrm{~h}$ prior to occupation of station 238 there had been significant precipitation, whereas during the hours before occupation of station 241 no precipitation was reported (Table S.4). Wet deposition by precipitation in commonly lower $\mathrm{pH}$ rainwater (as compared to high $\mathrm{pH} \sim 8.1$ of seawater) is deemed too strongly enhanced dissolution of dust, relative to dry deposition (Jickells and Spokes, 2001; De Baar and De Jong, 2001).

The $400 \mathrm{~m}$ deep station above the Patagonian shelf, close to Tierra del Fuego, showed high dissolved Fe concentrations in the upper $150 \mathrm{~m}$, where salinity was low (Fig. 2b, $5 a)$. There was a strong inverse correlation between DFe and salinity $\left(R^{2}=0.85, P<0.001, n=11\right)$, pointing towards fluvial input of DFe. Similar high concentrations and correlations were observed for DMn and DAl (Middag et al., 2012). This DFe maximum is only observed in the most northern station, above the shelf (Fig. 5a), but does not extend far into the Drake Passage. The latter may be explained by the very strong eastward velocity in this region ( $>40 \mathrm{~cm} \mathrm{~s}^{-1}$; Renault et al., 2011) bringing the elevated Fe signal more eastward than the other stations of our section. Although the amount of freshwater flowing into the Drake Passage is relatively small, the order of magnitude higher DFe in these freshwater influenced waters compared to the non-freshwater influenced Drake Passage surface waters, may have caused substantial DFe enrichment of the surface waters to the east of Tierra de Fuego.

\subsubsection{Deep waters of Drake Passage}

In the Southern Drake Passage, around $59-60^{\circ} \mathrm{S}$, a strong enrichment in DFe was observed in the bottom waters $(>3000 \mathrm{~m})$ (Fig. 5a). This enrichment was also observed in the concentrations of DMn and DAl (Middag et al., 2012). These enrichments could be caused by downslope convection of dense water along the peninsula slope. Meredith et al. (2003) reported a direct ventilation of deep waters in the Drake Passage by dense shelf waters north of Elephant Island. However, this mechanism was only observed during and after austral winter, and was strongest in (positive) ENSO years. Since 2008 had a strong negative ENSO index (Jullion et al., 2010), it would seem unlikely this episodic mechanism is responsible for the elevated deep concentrations in the fast flowing waters of Drake Passage. Sudre et al. (2011) have shown that WSDW may follow a westward direction upon leaving the Weddell Sea through the gaps in the south Scotia Ridge. This is also confirmed for our cruise, by $\mathrm{Th} / \mathrm{Pa}$ istopes as reported by Venchiarutti et al. (2011). Huhn et al. (2008) reported a similar pathway for WSBW formed along the peninsula slope in the western Weddell Sea. Concentrations of DFe in the deep waters in the southern Drake Passage were significantly higher than those in the WSDW and WSBW in the Weddell Sea (Fig. 2); similar to DMn and DAl (Middag et al., 2012). Thus there is likely a source of trace elements during transport from the Weddell Sea to Drake Passage. Although hydrothermal vents are present in this region (Klinkhammer et al., 2001), DFe enrichment by mixing with hydrothermally influenced waters is unlikely, as this would have been reflected in enhanced $\delta^{3} \mathrm{He}$ concentrations, which were not observed for this region (Sudre et al., 2011). The lowered light transmission (Middag et al., 2012) in these water masses was an indication of resuspended particles, likely picked up during transport from the Weddell Sea to the Drake Passage. Dissolution of these particles or mixing with DFe-rich pore waters during this resuspension was the likely reason for the observed high $\mathrm{DFe}$ concentrations. This mechanism has also been suggested for DMn and DAl by Middag et al. (2012).

A layer with an anomalously high DFe concentration (up to $1.94 \mathrm{nM}$ ) was observed towards the South American flank of the Drake Passage, at $\sim 2000-3000 \mathrm{~m}$ depth coinciding with SPDSW. This water mass originates from the East Pacific Rise, carrying a significant $\delta^{3} \mathrm{He}$ signal as a result of the 
hydrothermal activity at the East Pacific Rise (see Sect. 4). Middag et al. (2012) reported a clear trend between $\delta^{3} \mathrm{He}$ and DMn, both good indicators for hydrothermal vents, in this water mass. We assume the high concentrations of DFe in the SPDSW water were also caused by hydrothermal activity. Although the volume of this water mass is small, the large difference in $\mathrm{DFe}(1.5-2 \mathrm{nM})$ relative to its surrounding deep water masses $(\sim 0.5 \mathrm{nM})$ resulted in the SPDSW as a source of DFe to the deep waters in the Drake Passage, and eventually to the deep South Atlantic Ocean.

\section{Summary and conclusions}

Surface DFe concentrations where observed to be extremely depleted $(\sim 0.01 \mathrm{nM})$ in the central Weddell Sea. Generally, concentrations were $<0.1 \mathrm{nM}$ in the upper $100 \mathrm{~m}$. These low DFe concentrations could have been (partly) explained by primary productivity in the surface waters, stressing the important role of biological processes in controlling the DFe distribution. The only DFe input from the Antarctic Peninsula shelf was observed above the shelf itself, with little sign of advection of this DFe into the Weddell Basin. In the Weddell Sea, no clear influence of the shelf was observed in the seasonal nutrient drawdown, although it should be noted that no winter water was observed north of $64^{\circ} \mathrm{S}$, and thus no removal values could be reported close to the shelf. The $\mathrm{N}$ : Si removal ratio was lower in low DFe regions indicating $\mathrm{DFe}$ control on the algal nutrient uptake ratios and eventually on algal growth. In the Eastern Weddell Gyre, no effect of DFe on the N:P removal ratio $(\sim 13)$ was observed. Along the Greenwich Meridian, however, the N:P removal ratio increased with increasing $\mathrm{DFe}$. This difference between regions was likely caused by differences in diatom size; the diatoms at the Greenwich Meridian were significantly larger. Low DFe concentrations relative to deep water concentrations observed worldwide were observed in the deep water masses of the Weddell Sea. The difference in deep water DFe concentrations between the transect here presented and the $0^{\circ} \mathrm{W}$ transect indicated significant enrichment of deep waters with DFe during eastward transit along the Scotia Ridge. There was an indication of some DFe enrichment with formation of WSBW by downslope convection of shelf waters. However, the small difference in DFe between WSBW and WSDW suggested that this was not a significant DFe source to the WSDW. In the Drake Passage, close to Elephant Island, strong $(\sim 2 \mathrm{nM})$ DFe input from the shelf was observed, following the same isopycnals as earlier observed for shelf water input in this region. The scale length of $\sim 200 \mathrm{~km}$ indicated that DFe enrichment did extend into the Drake Passage. Most likely the influence was more profound to the east due to the strong eastward velocities of the ACC. Generally, surface waters in the Drake Passage had low DFe concentrations $(<0.2 \mathrm{nM})$, as a result of biological removal, both regionally and "upstream" of the ACC, in the remote South Pacific. Lo- cally, DFe enrichments caused by atmospheric $\left(58.3^{\circ} \mathrm{S}\right.$; station 238) or fluvial input sources (55.1 ${ }^{\circ} \mathrm{S}$; station 252 , above Patagonian shelf) were observed. Dissolved Fe concentrations of $>1 \mathrm{nM}$ were observed in the deep waters in the southern Drake Passage, most likely related to WSDW and WSBW inflow, enriched with DFe by sediment and porewater resuspension or a flux from the porewaters during transit over the Scotia Ridge. In the central Drake Passage, the distribution of DFe generally followed the water masses, with highest DFe in the circumpolar deep waters. Towards the South American continental shelf, a strong DFe enrichment was observed in the SPDSW, most likely related to hydrothermal vents in the source region of this water mass.

\section{Supplementary material related to this article is available online at http://www.biogeosciences.net/11/651/ 2014/bg-11-651-2014-supplement.zip.}

Acknowledgements. The authors are most grateful to the master and crew of FS Polarstern for their excellent support and commitment during ANT XXIV-3. We would also like to thank Sven Ober from NIOZ and Gerd Rohardt from the Alfred Wegener Institute for providing the physical parameters. We commemorate our colleague Willem Polman who unfortunately did not return from ANT XXIV-3. We also commemorate our helpful and dedicated cruise leader Prof. Eberhardt Fahrbach. Finally, we would like to thank M. Rijkenberg and P. Sedwick and two anonymous reviewers for their constructive comments.

Edited by: K. Fennel and K. Suzuki

\section{References}

Alderkamp, A.-C., de Baar, H. J. W., Visser, R. J. W., and Arrigo, K. R.: Can photo inhibition control phytoplankton abundance in deeply mixed water columns of the Southern Ocean?, Limnol. Oceanogr., 55, 1248-1264, 2010.

Alderkamp, A.-C., Garcon, V., De Baar, H. J. W., and Arrigo, K. R.: Short-term photoacclimation effects on hotoinhibition of phytoplankton in the Drake Passage (Southern Ocean), Deep Sea Res. Pt. I, 58, 943-955, 2011.

Alvain, S., Moulin, C., Dandonneau, Y., and Loisel, H.: Seasonal distribution and succession of dominant phytoplankton groups in the global ocean: a satellite view, Global Biogeochem. Cy., 22, GB3001, doi:10.1029/2007/GB003154, 2008.

Ardelan, M. V., Holm-Hansen, O., Hewes, C. D., Reiss, C. S., Silva, N. S., Dulaiova, H., Steinnes, E., and Sakshaug, E.: Natural iron enrichment around the Antarctic Peninsula in the Southern Ocean, Biogeosciences, 7, 11-25, doi:10.5194/bg-7-11-2010, 2010.

Baars, O. and Croot, P.: The speciation of dissolved zinc in the Atlantic Sector of the Southern Ocean, Deep-Sea Research II, 58, 2720-273, 2011. 
Blain, S., Quéguiner, B., Armand, L., Belviso, S., Bombled, B., Bopp, L., Bowie, A., Brunet, C. Brussaard, C., Carlotti, F., Christaki, A., Corbière, A., Durand, I., Ebersbach, F., Fuda, J.-L., Garcia, N., Gerringa, L., Griffiths, B., Guigue, C., Guillermo, C., Jacquet, S., Jeandel, C., Laan, P., Lefèvre, D., Lo Monaco, D., Malits, A., Mosseri, J., Obernosterer, I., Park, Y.-H., Picheral, M., Pondaven, P., Remenyi, T, Sandroni, V., Sarthou, G., Savoye, N., Scouarnec, L., Souhaut, M., Thuiller, D., Timmermans, K., Trull, T., Uitz, J., van Beek, P., Veldhuis, M., Vincent, D., Viollier, E., Vong, L., and Wagener, T.: Effect of natural iron fertilization on carbon sequestration in the Southern Ocean, Nature, 44, 10701074, doi:10.1038/nature05700, 2011.

Bluhm, K., Croot P., Huhn O., Rohardt G., and Lochte K.: Distribution of Iodide and iodate in the Atlantic sector of the southern ocean during austral summer, Deep-Sea Res. II, 58, 2733-2748, 2011

Borrione, I. and Schlitzer, R.: Aqua MODIS satellite measurements over the Scotia Sea: spatial and temporal variability of phytoplankton blooms, 2010 Ocean Sciences Meeting, 2010

Boyd, P. W., Jickells, T., Law, C. S., Blain, S., Boyle, E. A., Buesseler, K. O., Coale, K. H., Cullen, J. J., De Baar, H. J. W., Follows, M., Harvey, M., Lancelot, C., Levasseur, M., Owens, N. J. P., Pollard, R., Rivkin, R. B., Sarmiento, J., Schoemann, V., Smetacek, V., Takeda, V., Tsuda, A., Turner, S., and Watson, A: Mesoscale iron enrichment experiments 1993-2005: synthesis and future directions, Science, 315, 612-617, 2007.

Bucciarelli, E., Blain, S., and Tréguer, S.: Iron and manganese in the wake of the Kerguelen Islands Southern Ocean, Mar. Chem., $73,21-36,2001$

Buma, A. G. J., De Baar, H. J. W., Nolting, A. J., and van Bennekom, R. F.: Metal enrichment experiments in the WeddellScotia Seas: Effects of iron and manganese on various plankton communities, Limnol. Oceanogr., 36, 1865-1878, 1991

Cassar, N., Bender, M. L. , Barnett, B. A., Fan, S., Moxim, W. J., Levy II, H., and Tilbrook, B.: The Southern Ocean biological response to aeolian iron deposition, Science, 317, 1067-1070, 2007.

Charrette, M.: The Role of Ocean Mixing in Southern Ocean Ironfueled Phytoplankton Blooms: Insight from Radium Isotopes, Presentation at the The Modeling and Synthesis of Southern Ocean Natural Iron Fertilization Workshop, Woods Hole, Monday June 27, 2011.

Chever, F., Sarthou, G., Bucciarelli, E., Blain, S., and Bowie, A. R.: An iron budget during the natural iron fertilisation experiment KEOPS (Kerguelen Islands, Southern Ocean), Biogeosciences, 7, 455-468, doi:10.5194/bg-7-455-2010, 2010a.

Chever, F., Bucciarelli, E., Sarthou, G., Speich, S., Arhan, M., Penven, P., and Tagliabue, A: Physical speciation of iron in the Atlantic sector of the Southern Ocean along a transect from the subtropical domain to the Weddell Sea Gyre, J. Geophys. Res., 115, C10059, doi:10.1029/2009JC005880, 2010b.

Croot, P. L., Andersson, K., Öztürk, M., and Turner, D. R.: The distribution and speciation of iron along $6^{\circ} \mathrm{E}$ in the Southern Ocean, Deep-Sea Res. Pt. II, 51, 2857-2879, 2004.

Croot., P. L., Baars, O., and Streu, P.: The distribution of dissolved zinc in the Atlantic Sector of the Southern Ocean, Deep-Sea Res. II, 58, 2707-2719, 2011.

De Baar, H. J. W. and de Jong, J. T. M: Distributions, sources and sinks of iron in seawater, in: Biogeochemistry of Iron in Seawa- ter, IUPAC Book Series on Analytical and Physical Chemistry of Environmental Systems, edited by: Turner, D. and Hunter, K. A., 7, 123-254, 2001.

De Baar, H. J. W., Buma, A. G. J., Nolting, R. F., Cadée, G. C., Jacques G., and Tréguer, P. J.: On iron limitation of the Southern Ocean: experimental observations in the Weddell and Scotia Seas, Mar. Ecol. Prog. Ser., 65, 105-122, 1990.

De Baar, H. J. W., De Jong, J. T. M., Bakker, D. C. E., Löscher, B., Veth, C., Bathman, U., and Smetacek, V.: Importance of iron for plankton blooms and carbondioxide drawdown in the Southern Ocean, Nature, 373, 412-415, 1995.

De Baar, H. J. W., van Leeuwe, M. A., Scharek, R., Goeyens, L., Bakker, K. M. J., and Fritsche,P.: Nutrient anomalies in Fragilariopsis Kerguelensis blooms, iron deficiency and the nitrate/phosphate ratio (A. C. Redfield) of the Antarctic Ocean, Deep-Sea Res. II, 44, 229-260, 1997.

De Baar, H. J. W., de Jong J. T. M., Nolting, R. F, Timmermans, K. R., van Leeuwe, M. A., Bathmann, U., Rutgers van der Loeff, M., and Sildam, J.: Low dissolved Fe and the absence of diatom blooms in the remote South Pacific Ocean, Mar. Chem., 66, $1-34,1999$.

De Baar, H. J. W., Boyd, P. W. , Coale, K. H., Landry, M. R., Tsuda, A., Assmy, P., Bakker, D. C. E., Bozec,Y., Barber, R. A., Brzezinski, M. A., Buesseler, K. O., Boyé, M., Croot, P. L., Gervais, F., Gorbunov, M. Y., Harrison, P. J., Hiscock, W. T., Laan, W. T., Lancelot, C., Law, C., Levasseur, M., Marchetti, A., Millero, F. J., Nishioka, J., Nojiri, Y., Oijen, T. V., Riebesell, U., Rijkenberg, M. J. A., Saito, H., Takeda, S., Timmermans, K. R., Veldhuis, M. J. W., Waite, A., and Wong, C. S.: Synthesis of Iron Fertilization Experiments: From the Iron Age in the Age of Enlightenment, in: The Oceans in a High- $\mathrm{CO}_{2}$ World, edited by: Orr, J. C., S. Pantoja, and H.-O. Pörtner, Special Issue of J. Geophys. Res. C (Oceans), 110, 1-24, 2005.

Duce, R. A. and Tindale, N. W.: Atmospheric transport of iron and its deposition in the ocean, Limnol. Oceanogr., 36, 1715-1726, 1991.

Dulaiova, H., Ardelan, M. V., Henderson, P. B., and Charette M A.: Shelf-derived iron inputs drive biological productivity in the southern Drake Passage, Global Biogeochem. Cy., 23, GB4014, doi:10.1029/2008GB003406, 2009.

Elrod, V. A., Berelson, W. M., Coale, K. H., and Johnson, K. S.: The flux of iron from continental shelf sediments: amissing source for global budgets, Geophys. Res. Lett., 31, doi:10.1029/2004GL020216, 2004

Fahrbach, E., Rohardt, G., Schroder, M. V., and Strass, V.: Transport and structure of the Weddell Gyre, Ann. Geophysicale, 12, 840855, 1994.

Fahrbach, E., Hoppema, M., Rohardt, G., Boebel, O., Klatt, O., Wisotzki, A., Warming of deep and abyssal water massess along the Greenwich Meridian on decadal time scales: The Weddell Gyre as heat buffer, Deep-Sea Res. II, 58, 2509-2523, 2011.

Gerringa, L. J. A., Alderkamp, A. C., Laan, P., Thuróczy, C.-E., De Baar, C.-E., Mills, M. M., van Dijken, G. L., Haren, H., and VanArrigo, K. R.: Fe from melting glacier fuels the algal bloom in Pine Island Bay (Amundsen Sea, Southern Ocean). Deep-Sea Research II 71-76 16-31, 2012.

Haine, T. W. N., Watson, A. J., Liddicoat, M. I., and Dickson, R. R.: The flow of Antarctic Bottom Water the Southwestern Indian 
Ocean estimated using CFC's, J. Geophys. Res., 103, 2763727653, 1998.

Hewes, C. D., Reiss, C. S., and Holmansen, O.: A quantitative analysis of sources for summertime phytoplankton variability over 18 years in the South Shetland Islands (Antarctica) region, DeepSea Res. Pt. I, 56, 1230-1241, 2009.

Heygster, G., Melsheimer, C., and Notholt, J.: Institute of Environmental Physics, University of Bremen, Germany, Sept. 2007, Sep.2011. AMSR images: http://iup.physik.uni-bremen.de: 8084/amsredata/asi_daygrid_swath/11a/s6250/2008/mar/ asi-s6250-20080314-v5_nic.pdf, 2011.

Hiscock, M. R., Marra, J., Smith Jr., W. O., Goericke, R., Measures, C. I., Vink, S., Olson, R. J., Sosik, H. M., and Barber, R. T.: Primary productivity and its regulation in the Pacific Sector of the Southern Ocean, Deep-Sea Res. II, 50, 533-558, 2003.

Hoffman, L. J., Peeken, I., Lochte, K., Assmy, P., and Veldhuis, M.: Different reactions of Southern Ocean phytoplankton size classes to iron fertilization, Limnol. Oceanogr., 51, 1217-1229, 2006.

Hopkinson B. M., Mitchell, G., Reynolds, R. A. Wang, H. Selph, K. E., Measures, C. I., Hewes, C. D., Holm-Hansen, O., and Barbeau, K. A.: Iron limitation across chlorophyll gradients in the southern Drake Passage: Phytoplankton responses to iron addition and photosynthetic indicators of iron stress, Limnol. Oceanogr., 52, 2540-2554, 2007.

Hoppema, M., De Baar, H. J. W., Bellerby, R. G. J., Fahrbach, E., and Bakker, K.: Annual production in the interior Weddell Gyre estimated from a chemical mass balance of nutrients, Deep-Sea Res. II, 49, 1675-1689, 2002.

Hoppema, M., De Baar, H. J. W., Fahrbach, E., Hellmer, H., and Klein, B.: Substantial advective iron loss diminishes phytoplankton production in the Antarctic Zone, Global Biogeochem. Cy., 17, 1-9, 2003.

Hoppema M., Middag, R., De Baar, H. J. W., Fahrbach, E., van Weerlee, E. M., and Thomas, H.: Whole season net community production in the Weddell Sea, Polar Biol., 31, 101-111, 2007.

Hoppema, M., Dehairs, F., Navez, J., Monnin, C., Jeandel, C., Fahrbach, E., and De Baar, H. J. W.: Distribution of barium in the Weddell Gyre: Impact of circulation and biogeochemical processes, Mar. Chem., 122, 118-129, 2010.

Huhn, O., Hellmer, H. H., Rhein, M. , Rodehacke, C., Roether, W., Schodlok, M. P., and Schröder, M.: Evidence of deep- and bottom-water formation in the western Weddell Sea, Deep-Sea Res. II, 55, 1098-1116, 2008.

Jickells, T. D. and Spokes, L. J.: Atmospheric iron inputs to the oceans, in: Biogeochemistry of Iron in Seawater, IUPAC Book Series on Analytical and Physical Chemistry of Environmental Systems, edited by: Turner, D. and Hunter, K. A., 7, 123-254, 2001.

Jullion, L., Jones, S. C., Naveira Garabato, A. C., and Meredith, M.P.: Wind-controlled export of Antarctic Bottom Water from the Weddell Sea, Geophys. Res. Lett., 37, L09609, doi:10.1029/2010GL042822, 2010,

Kahru, M., Mitchell, B. G., Gille, S. T., Hewes, C. D., and Holm-Hansen, O.: Eddies enhance biological production in the Weddell-Scotia Confluence of the Southern Ocean, Geophys. Res. Lett., 34, L14603, doi:10.1029/2007GL030430, 2007,

Klatt, O., Fahrbach, E., Hoppema, M., and Rohardt, G.: The transport of the Weddell Gyre across the Prime Meridian, Deep-Sea Res. II, 52, 513-528, 2005.
Klinkhammer, G. P., Chin, C. S., Keller, R. A., Dählman, A., Sahling, H., Sarthou, G., Petersen, S., Smith, F., and Wilson, C.: Discovery of new hydrothermal vent sites in Bransfield Strait, Antarctica, Earth Planet. Sci. Lett., 193, 395-407, 2001.

Klunder, M. B., Laan, P., Middag, R., de Baar, H. J. W., and van Ooijen, J. C.: Dissolved Fe in the Southern Ocean (Atlantic sector), Deep-Sea Res. II, 58, 2678-2694, 2011a.

Klunder, M. B., Bauch, D., Laan, P., De Baar, H. J. W., van Heuven, S., and Ober, S.: Dissolved iron in the Arctic shelf seas and surface waters of the Central Arctic Ocean: Impact of Arctic river water and ice melt, J. Geophys. Res. Oc., 117, C01027, doi:10.1029/2011JC007133, 2011b.

Lancelot, C., Hannon, E., Becquevort, E., Veth, C., and De Baar, H. J. W.: Modelling phytoplankton blooms and carbon export production in the Southern Ocean: dominant controls by light and iron in the Atlantic sector in Austral spring 1992, Deep-Sea Res. Pt. I, 47, 1621-1662, 2000.

Lancelot, C., de Montety, A., Goosse, H., Becquevort, S., Schoemann, V., Pasquer, B., and Vancoppenolle, M.: Spatial distribution of the iron supply to phytoplankton in the Southern Ocean: a model study, Biogeosciences, 6, 2861-2878, doi:10.5194/bg-62861-2009, 2009.

Laës, A., Blain, S., Laan, P. , Achterberg, E. P.,Sarthou, G., and De Baar, H. J. W.: Deep dissolved iron profiles in the eastern North Atlantic in relation to watermasses, Geophys. Res. Lett., 30, 1-3, 2003.

Lannuzel, D., Schoemann, V., De Jong, J.T.M., Chou, L., Delille, B., Becquevort, S., and Tison, J.-L.: Iron study during a time series in the western Weddell pack ice, Mar. Chem., 108, 85-95, 2008.

Lösscher, B., De Baar, H. J. W., De Jong, J. T. M., Veth, C., and Dehairs, F.: The distribution of Fe in the Antarctic Circumpolar Current, Deep-Sea Res. II, 44, 143-187, 1997.

Lin, H., Rauschenberg, S., Hexel, C. R., Shaw, T. J., and Twining, B. S.: Free drifting icebergs as sources of iron to the Weddell Sea, Deep-Sea Res. II, 58, 1392-1406, 2011.

Luther III, G. W. and Wu, J.: What controls dissolved iron concentrations in the world ocean? - a comment, Mar. Chem., 57, 174-181, 1997.

Marchetti, A. and Cassar, N.: Diatom elemental and morphological changes in response to iron limitation: a brief review with potential paleoeanographic applications, Geobiology, 7, 419-431, 2009.

Martin, J. H. and Fitzwater, S. E.: Iron deficiency limits phytoplankton growth in the north-east Pacific subarctic, Nature, 331, 341343, 1988.

Martin, J. H., Gordon, R. M., and Fitzwater, S. E.: Iron in Antarctic waters, Nature, 345, 156-158, 1990.

Matano, R. P., Gordon, A. L., Muench, R. D., and Palma, E. D.: A numerical study of the circulation in the northwestern Weddell Sea, Deep-Sea Res. II, 49, 4827-4841, 2002.

Meredith, M. P., Hughes, C. W., and Foden, P. R.: Downslope convection north of Elephant Island, Antarctica: Influence on deep waters and dependence on ENSO, Geophys. Res. Lett., 30, 1462, doi:10.1029/2003GL017074, 2003.

Middag, R., de Baar, H. J. W., Laan, P., Cai, P. H., and van Ooijen, J. C.: Dissolved manganese in the Atlantic sector of the Southern Ocean, Deep-Sea Res. II, 58, 2661-2677, 2011 a. 
Middag, R., Van Slooten, C., de Baar, H. J. W., and Laan, P.: Dissolved aluminium in the Atlantic sector of the Southern Ocean, Deep-Sea Res. II, 58, 2647-2660, 2011 b.

Middag, R., de Baar, H. J. W., Laan P., and Huhn, O.: The effects of continental margins and water mass circulation on the distribution of dissolved aluminium and manganese in Drake Passage, J. Geophys. Res., 117, C01019, doi:10.1029/2011JC007434, 2012.

Middag, R., de Baar, H. J. W., Klunder, M. B., and Laan, P.: Fluxes of dissolved aluminum and manganese to the Weddell Sea and indications for manganese co-limitation, Limnol. Oceanogr., 58, 287-300, 2013.

Mitchell, G. B. and Holm-Hansen, O.: Observations of modelling of the Antartic phytoplankton crop in relation to mixing depth, Deep-Sea Res. Pt. A, 38, 981-1007, 1991.

Moore, J. K. and Abbott, M. R.: Surface chlorophyll concentrations in relation to the Antarctic Polar Front: seasonal and spatial patterns from satellite observations, J. Mar. Syst., 37, 69-86, 2002.

Neven, I., Stefels, J., van Heuven, S., De Baar, H. J. W., and Elzinga, J. T. M: High plasticity in inorganic carbon uptake by Southern Ocean phytoplankton in response to ambient $\mathrm{CO}_{2}$, Deep-Sea Res. II, 58, 2636-264, 2011.

Naveira Garabato, A. C., McDonagh, E. L., Stevens, D. P., Heywood, K. J., Sanders, R. J.: On the export of Antarctic Bottom Water from the Weddell Sea, Deep-Sea Res. II, 49, 4715-4742, 2002

Orsi, A. H., Nowlin Jr., W. D., and Whitworth III, T.: On the circulation and stratification of the Weddell Gyre, Deep-Sea Res. I, 40, 169-203, 1993.

Planquette, H., Statham, P. J., Fones, G. R., Charette, M. A., Mark Moore, C., Salter, I., Nedelec, F. H., Taylor, S. L., French, M., Baker, A. R., Mahowald, N., and Jickells, T. D.: Dissolved iron in the vicinity of the Crozet Islands, Southern Ocean, Deep-Sea Res. II, 54, 1999-2019, 2007.

Pollard, R. T., Lucas, M. I., and Read, J. F.: Physical controls on biogeochemical zonation in Southern Ocean, Deep-Sea Res. Part II, 49, 3931-3950, 2002.

Raiswell, R.: Iceberg-hosted nanoparticulate Fe in the Southern Ocean: Mineralogy, origin, dissolution kinetics and source of bioavailable Fe, Deep-Sea Res. II, 58, 1364-137, 2011.

Renault, A., Provost, C., Sennechael, N., Barré, N., and Kartavtseff, A.: Two full-depth velocity sections in the Drake Passage in 2006 - Transport estimates, Deep-Sea Res. II, 58, 2572-2591, 2011.

Rijkenberg, M., De Baar, H., and Laan, P.: Dissolved Fe in the Western Atlantic Ocean: Distribution, Sources, Sinks and Cycling Goldschmidt Conference, August, 2011.

Rutgers van der Loeff, M., Cai, P., Stimac, I., Bracher, A., Middag, R., Klunder, M.B., and van Heuven, S.: ${ }^{234}$ Th in surface waters: distribution of particle export flux across the Antarctic Circumpolar Current and in the Weddell Sea during the GEOTRACES expedition ZERO and DRAKE, Deep-Sea Res. II, 58, 2749-2766, 2011.

Salter, I., Lampitt, R. S., Sanders, R., Poulton, A. ,Kemp, A. E. S., Boorman, B., Saw, K., and Pearce, R.: Estimating carbon, silica and diatom export from a naturally fertilised phytoplankton bloom in the Southern Ocean using PELAGRA: A novel drifting sediment trap, Deep-Sea Res. II, 54, 2233-2259, 2007.
Saňudo-Wilhelmy, S. A., Olsen, K. A., Scelfo, J. M., Foster, T. D., and Flegal, A. R.: Trace metal distributions off the Antarctic Peninsula in the Weddell Sea, Mar. Chem., 77, 157-170, 2002.

Sarthou, G., Timmermans, K. R., Blain, S., and Tréguer, P.: Growth physiology and fate of diatoms in the ocean: a review, J. Sea Res., 53, 25-42, 2005.

Smetacek, V., Klaas, C., Strass, V. Assmy, P., Montresor, M., and Cisewski, B.: Deep carbon export from a Southern Ocean ironfertilized diatom bloom, Nature, 487, 313-319, 2012.

Sokolov, S. and Rintoul, S. R.: On the relationship between fronts of the Antarctic Circumpolar Current and surface chlorophyll concentrations in the Southern Ocean, J. Geophys. Res., 112, C07030, doi:10.1029/2006JC004072, 2007.

Stuart, K. M. and Long, D. G.: Tracking large tabular icebergs using the SeaWinds Ku-band microwave scatterometer, Deep-Sea Res. Part II, 58, 1285-1300, 2011.

Sudre, J., Garçon, V., Provost, C., Sennechael, Huhn, O., and Lacombe, M.: Multiparametric analysis of water masses across Drake Passage during ANT-XXIII/3, Deep-Sea Res. II, 58, 2592-2612, 2011.

Takeda, S.: Influence of iron availability on nutrient composition ratio of diatoms in oceanic waters, Nature, 393, 774-777, 1998.

Thuroćzy, C. E. T., Gerringa, L. J. A., Klunder, M. B., Middag, R., Laan, P., Timmermans, K. R., and De Baar, H. J. W.: Speciation of Fe in the Eastern North Atlantic Ocean, Deep-Sea Res. I, 57, 1444-1453, 2010.

Timmermans, K. R., Van de Wagt, B., and De Baar, H. J. W.: Growth rates, half-saturation constants, and silicate, nitrate, and phosphate depletion in relation to iron availability of four large, open-ocean diatoms from the Southern Ocean, Limnol. Oceanogr., 49, 2141-2151, 2005.

Vancoppenolle, M., Goosse, H., de Montety, A., Fichefet, T., Tremblay, B., and Tison, J.-L.: Modeling brine and nutrient dynamics in Antarctic sea ice: The case of dissolved silica, J. Geophys. Res., 115, C02005, doi:10.1029/2009JC005369, 2010.

Venchiarutti, C., Rutgers van der Loeff, M., and Stimac, I.: Scavenging of ${ }^{231} \mathrm{~Pa}$ and thorium isotopes based on dissolved and sizefractionated particle distributions at Drake Passage (ANTXXIV3), Deep-Sea Res. II, 58, 2767-2784, 2011.

Well, R., Roether, W., Stevens, D. P.: An additional deep water mass in Drake Passage as revealed by ${ }^{3} \mathrm{He}$ data, Deep-Sea Res. I, 50, 1079-1098, 2003

Weppernig R., Schlosser, P., Khatiwala, S., and Fairbanks, R. G. Isotope data from ice Station Weddell: implications for deep water formation in the Weddell Sea, J. Geophys. Res., 101, 25723 25739, 1996

Wright, S., W., van den Enden, R., Pearce, I., Davidson, A. T., Scott, F. J., and Westwood, K. J.: Phytoplankton community structure and stocks in the Southern Ocean $\left(30-80^{\circ} \mathrm{E}\right)$ determined by CHEMTAX analysis of HPLC pigment signatures, Deep Sea Res. II, 57, 758-778, 2010. 